Alain MARIAUX ${ }^{1}$

Translation by Ilona BosSANYI ${ }^{2}$

${ }^{1}$ Research Engineer in wood sciences Department of Anatomy

Centre Technique Forestier Tropical

(Cirad)

France

${ }^{2}$ Bois et Forêts des Tropiques Translation from the original articles published in French in issues 113 and 114 of Bois et Forêts des Tropiques, 1967.

Taxonomic references updated by Michel Arbonnier.

Please cite as: Mariaux A. (2016). Nature and periodicity of growth rings in African timber: Can they be used to determine the age of trees?

(I. Bossanyi, Trans.).

Bois et Forêts des Tropiques, 327: 57-82.

\section{Nature and periodicity of growth rings in African timber: Can they be used to determine the age of trees?}

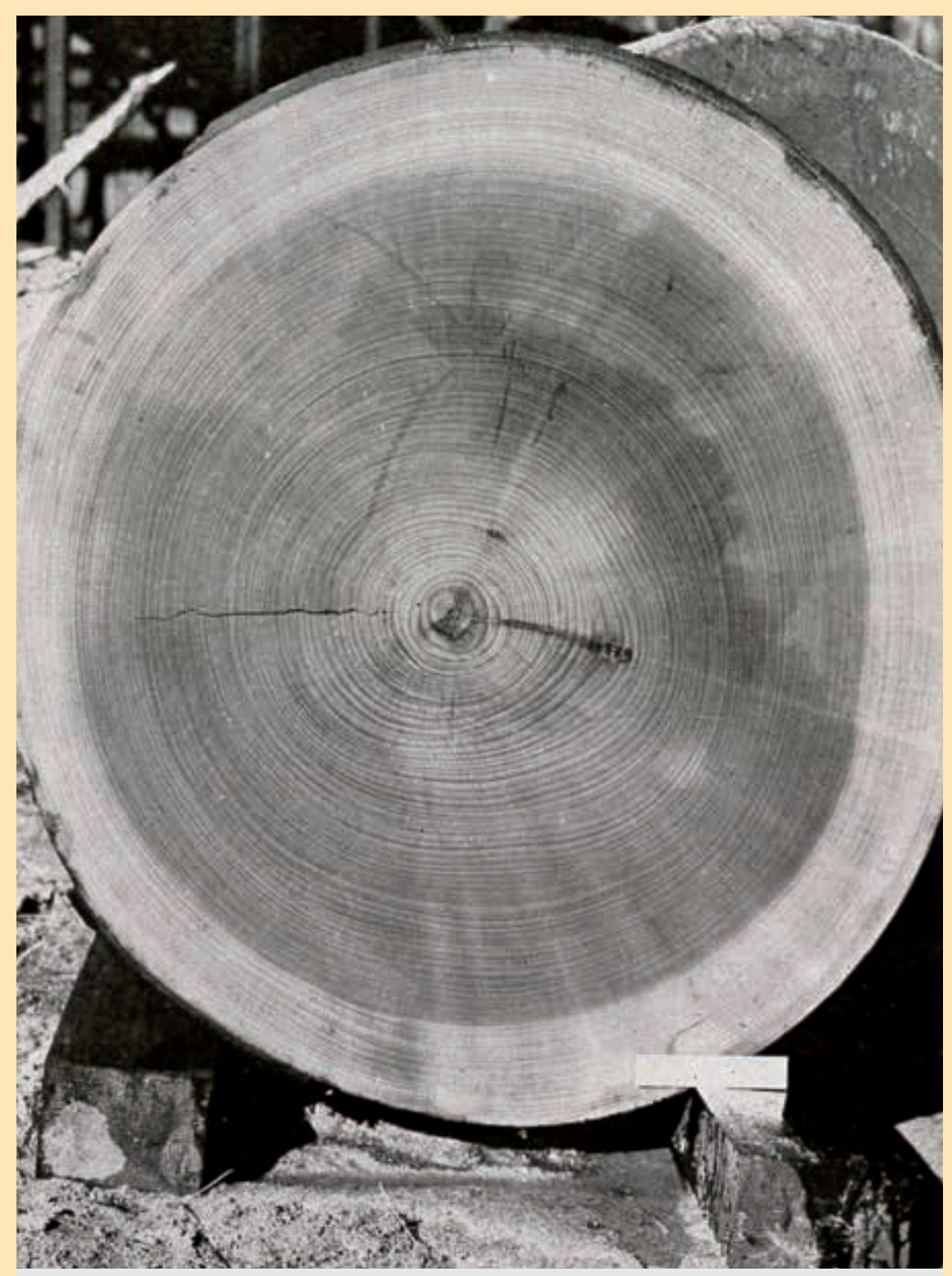

Photo 1.

A $90 \mathrm{~cm}$ cross-section of an okoume, Aucoumea klaineana Pierre, sanded and moistened to bring out the tree rings.

Photo A. Châtelain. 


\section{RÉSUMÉ}

\section{LES CERNES DANS LES BOIS TROPICAUX AFRICAINS, NATURE ET PÉRIODICITÉ : PEUVENT-ILS RÉVÉLER L’ÂGE DES ARBRES ?}

Dans une démarche de planification de l'exploitation forestière, il est nécessaire de connaître à quel âge les arbres africains peuvent être exploités, ceci autant pour le bois d'œuvre en forêt dense humide que pour le bois énergie en savane. Or, le suivi de la croissance sur plusieurs années est rarement assuré. Les cernes de croissance peuvent-ils dès lors fournir une estimation au moins approximative de l'âge des arbres exploitables ? Cet article méthodologique publié en français il y a bientôt 40 ans, aujourd'hui traduit en anglais, présente d'abord de manière générale et dans une première partie la nature et l'anatomie des cernes des arbres de bois africains. Il précise alors de quelle manière ces cernes, quand ils sont peu visibles à la loupe, peuvent être individualisés et comptabilisés par traitement mécanique de surface puis radiographie aux rayons $X$. La seconde partie est consacrée aux moyens de déterminer la périodicité de formation des cernes. Elle intègre bien entendu la difficulté principale représentée, pour une même espèce tropicale, par le décalage entre la croissance végétative et la succession des saisons. Diverses méthodes ont été utilisées dès les années 1920 pour analyser la dynamique de formation du bois chez des essences forestières tropicales. Les prélèvements périodiques de cambium réalisés en tournant autour de l'arbre constituent une méthode intéressante, cependant destructive. Des incisions pratiquées dans l'écorce laissent dans le bois des cicatrices qui permettent de dater différents points dans le bois. Une autre méthode consiste à pratiquer une incision annuelle et à poser un ruban dendrométrique autour de l'arbre, dont le suivi régulier et mensuel permet de révéler les périodes de formation du bois. Deux ans d'observation suffisent à obtenir de bons résultats.

Mots-clés : cernes, croissance, diamètre exploitable, rayon $\mathrm{X}$, bois tropicaux, Afrique.

\section{ABSTRACT}

RESUMEN

\section{NATURE AND PERIODICITY OF GROWTH RINGS IN AFRICAN TIMBER: CAN THEY BE USED TO DETERMINE THE AGE OF TREES?}

To draw up logging plans for African forests, it is essential to know at what age the trees can be felled, whether for timber from dense humid forests or for fuelwood from savannah areas. However, attempts are rarely made to monitor tree growth over a number of years. Could growth rings be used to provide at least an approximation of the age of trees marked for felling? This methodological article published nearly 40 years ago, and now translated into English, first gives an overview of the nature and anatomy of growth rings in African timber, explaining how, even when they are hard to discern with a magnifying glass, they can be counted individually by applying a mechanical treatment to the surface, followed by X-rays. The second part of the article discusses ways of determining the periodicity of growth ring formation, with a close look at the main difficulty that arises for tropical species, which is that growth rates in one and the same species do not necessarily match the seasonal cycle. Various methods have been used since the 1920 s to analyse the dynamics of wood formation in tropical tree species. Taking periodical samples of the cambium around the circumference of the trunk produces good results but the method is destructive. Incisions made into the bark leave scars from which different points in the wood can be dated. Another method involves making an incision each year and placing dendrometric tape around the tree. Regular monthly readings then show the exact periods when wood is being formed. Two years of observation are enough to produce good results.

Keywords: growth rings, growth, felling diameter, X-ray, tropical timber, Africa.

\section{NATURALEZA Y PERIODICIDAD DE LOS ANILLOS DE CRECIMIENTO EN MADERAS TROPICALES: ¿SIRVEN PARA SABER LA EDAD DE LOS ÁRBOLES?}

En un enfoque de planificación del aprovechamiento forestal es necesario saber a qué edad se pueden aprovechar los árboles africanos, tanto en el caso de la madera de selvas tropicales como la leña de sabanas. Sin embargo, el seguimiento del crecimiento durante varios años es muy poco frecuente. ¿Podemos entonces utilizar los anillos de crecimiento para tener una idea, al menos aproximada, de la edad de los árboles aprovechables? En su primera parte, este artículo metodológico, publicado hace casi 40 años en francés y hoy traducido al inglés, presenta primero de modo general la naturaleza y anatomía de los anillos de los árboles de maderas africanas. Luego se explica cómo individualizar y contabilizar dichos anillos, cuando son poco visibles con lupa, mediante tratamiento mecánico de superficie y además radiográfica con rayos $X$. La segunda parte se dedica a los medios para determinar la periodicidad en la formación de anillos. Evidentemente se aborda la principal dificultad, que consiste en el desfase entre crecimiento vegetativo y sucesión de estaciones en una misma especie tropical. Desde la década de 1920 se han utilizado diferentes métodos para analizar la dinámica de la formación de madera en las especies forestales tropicales. Las extracciones periódicas de cambium efectuadas girando alrededor del árbol son un método interesante, pero destructivo. Las incisiones en la corteza dejan cicatrices en la madera que permiten su datación en distintos puntos. Otro método consiste en practicar una incisión anual y colocar una cinta métrica alrededor del árbol que, gracias a un seguimiento regular y mensual, permitirá saber los períodos de formación de la madera. Dos años de observación bastan para lograr buenos resultados.

Palabras clave: anillos, crecimiento, diámetro aprovechable, rayos $\mathrm{X}$, madera tropical, África. 


\section{How old are the great trees of Africa's dense forests?}

For a long time, most foresters have taken it for granted that it is not possible to determine their age. Because there is no cold season, tree growth does not periodically stop and therefore does not produce countable rings in the wood.

Determining the age of trees raises many practical issues of current concern. This article discusses those that are most directly relevant to tropical foresters.

\section{How can growth rings be used to determine the age of trees?}

Development in tropical countries has occurred in parallel with a considerable increase in logging.

Due to the modern industrialised logging methods used in dense forests, production sites are becoming increasingly remote from the sites where the timber is used or exported. Large-scale planting programmes for commercial species are planned or already under way. However, for production planning as well as from the financial point of view, the time that will elapse before these plantations produce the desired timber is hypothetical in the extreme, unless the rate of growth of these species up to their minimum cutting diameter is known.

However, growth rates are still unknown for most tropical species for lack of observations covering their entire lifecycle, from planting to felling. Individual trees - okoume, mahogany, sipo, limba, samba or others - that were planted more than 50 years ago and have been regularly monitored since to ensure optimum growth, are so scarce as to be virtually non-existent.

It is certainly possible, in theory, to substitute direct knowledge with series of partial observations in the form of periodical measurements of tree sizes to determine average growth in diameter and the time taken to grow from one size category to the next. From this, the probable length of time needed to reach a given diameter can be assessed. But experience shows that it has rarely been possible to take series of periodical measurements of natural subjects of every size, up to the largest diameter class, over a sufficient number of years. Even today, when interest is focusing on these questions, it is not easy to monitor a meaningful sample of properly identified old-growth trees that are widely dispersed across a forested area. Furthermore, the results obtained in any given station cannot be extrapolated to other ecological contexts that differ in any way.

In dry regions, the concentration of fuelwood consumption in ever-growing population centres has created treeless zones across a radius of more than $20 \mathrm{~km}$ in some cases, and supplies are becoming very expensive in terms of local purchasing power. It has become necessary to manage fuelwood production through plans for regular felling in forest reserves, but the lack of data on the regeneration of coppice wood from shoots and seedlings is a problem.

In these regions, resources of construction wood, and even more so of high quality timber, are extremely limited, and production plans, even on a modest scale, require knowledge of the growth rates not only of local species of interest, such as Khaya senegalensis (Desr.) A. Juss. or Pterocarpus erinaceus Poir., but also of exotic species.

Mention should also be made of Faidherbia albida (Delile) A. Chev. (1934), which is well known in the SahelSudanian zone for shedding its leaves during the rainy season. Valued by herdsmen for its tender leaves that provide fodder for their herds during the dry season, it is now recognised by agronomists as promoting crop growth and protecting soils. Knowledge of its growth patterns is needed to find out whether wood production on a substantial scale could be considered on the basis of this symbiosis between trees and agriculture, and how long the renewal of high and regular tree cover would take.

However, we have no more knowledge on the growth of tree species in these dry regions than on the large dense forest species: only a few trials on managing fuelwood trees in regular cutting cycles have provided some insights on their potential overall production over 10 or 20 years.

Foresters in Africa have therefore come to consider the possibility of "reading" the age of trees from a cross-section of the trunk, a simple and time-saving method used by foresters in temperate countries.

In 1958, in Gabon, R. Catinot expressed the belief that growth rings in okoume wood could provide an estimation of tree age, with a margin of approximation to be determined, and that the potential gain would be worth the effort of overcoming the generally pessimistic view.

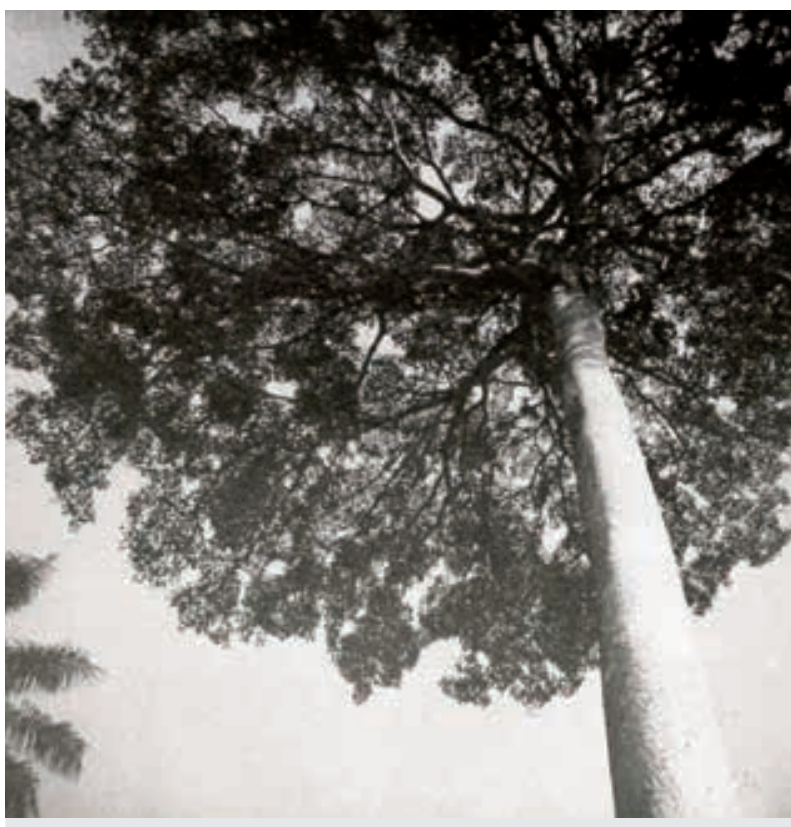

Photo 2.

An iroko tree (Milicia excelsa (Welw.) C.C. Berg) in Côte d'Ivoire: how many years did it take for this splendid tree to grow to its current size?

Photo A. Mariaux. 
This article describes how efforts to this end have been undertaken by the Centre Technique Forestier Tropical [now Cirad], after a discussion of the results obtained by other researchers in the tropics.

\section{Previous research}

We will not describe all of the studies that have been made on tree growth cycles. Some will be mentioned in connection with the methods we applied. Our first concern is to see whether it has already been demonstrated that growth rings can be used to determine the age of tropical tree species.

The earliest study that produced positive findings, to our knowledge, was made by Ch. Coster. From 1922 to 1926, in Java, he conducted observations and experiments on cambium activity and the aspect of growth rings. He investigated some 50 species, some in very different climatic stations. We quote the main points he made under the heading "Possibility of determining tree age by counting growth rings":

"In most tree species, the growth rings are so irregular and indistinct that successive counts can produce entirely different results. When this is the case, the result is not an age determination, but an estimation only.

With some species, however, especially in the climate cycle of Eastern Java, counting growth rings can produce results that are eminently usable to determine tree age.

However, the task is never as simple as in Europe, and a good deal of practice is needed to assess the age of many species with any accuracy."

Ch. Coster lists eight species in Eastern Java that produced accurate results, and 10 species with a $20 \%$ to $30 \%$ error in the number of years of growth. These figures must be viewed with caution, because the observations made on many other species are far too sketchy. The eight species for which there is the most certainty are Cassia fistula L., Pterocarpus indicus Willd., Toona sureni Merr. ${ }^{1}$, Melia azedarach L., Homalium tomentosum Benth. ${ }^{2}$, Lagerstroemia speciosa (L.) Pers., Tectona grandis L. f. and Peronema canescens Jack ${ }^{3}$.

K. A. Chowdhury monitored the rate of formation of woody layers in different species in India by periodically sampling the bark and wood from live trees, in the 1930 and 1940s. He noted the formation of annual growth rings from which years could be accurately counted in a pine species (Pinus roxburgii Sarg.), in teak (Tectona grandis L. f.) and in Terminalia tomentosa Wight \& Arn. (1834) ${ }^{4}$, Acacia catechu

1. Meliaceae Toona sureni Merr. - Interpr. Rumph. Herb. Amboin. 305 (1917). (IK). Revision of genus Toona in 1988 by Bahadur. Species native to South-East Asia and India.

2. Flacourtiaceae Homalium tomentosum Benth. - J. Proc. Linn. Soc., Bot. 4: 34. 1859 [1860 publ. 1859] (IK). Species native to Java.

3. Lamiaceae Peronema canescens Jack - Malayan Misc. ii. (1822) n. VII. 46. (IK) Malayan Miscellanies 2(7): 46. 1822. Species native to Malaya.

4. Combretaceae Terminalia tomentosa Mart. ex Eichler (improper name) - Fl. Bras. (Martius) 14(2): 97, in syn. 1867 [17 Apr 1867] (IK).

Terminalia tomentosa Wight \& Arn. (1834).

Terminalia tomentosa var. coriacea C.B. Clarke -The Flora of British India 2: 448. 1878. All species native to India.
(L. f.) Willd., Bombax ceiba L., Toona ciliata M. Roem., Magnolia champaca (L.) Baill. ex Pierre, Albizia lebbeck (L.) Benth. and Dalbergia sissoo Roxb. ex DC. He estimated that $25 \%$ of trees in India's dense forests had such growth rings.

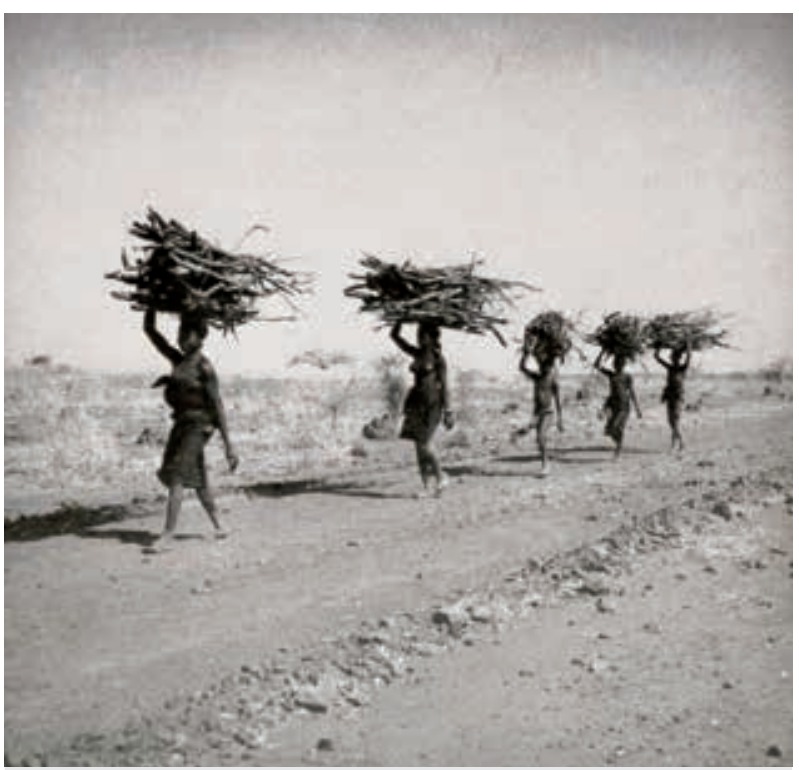

Photo 3.

In savannah areas, the women are tasked with carrying firewood into town over long distances. Photo Sarlin.

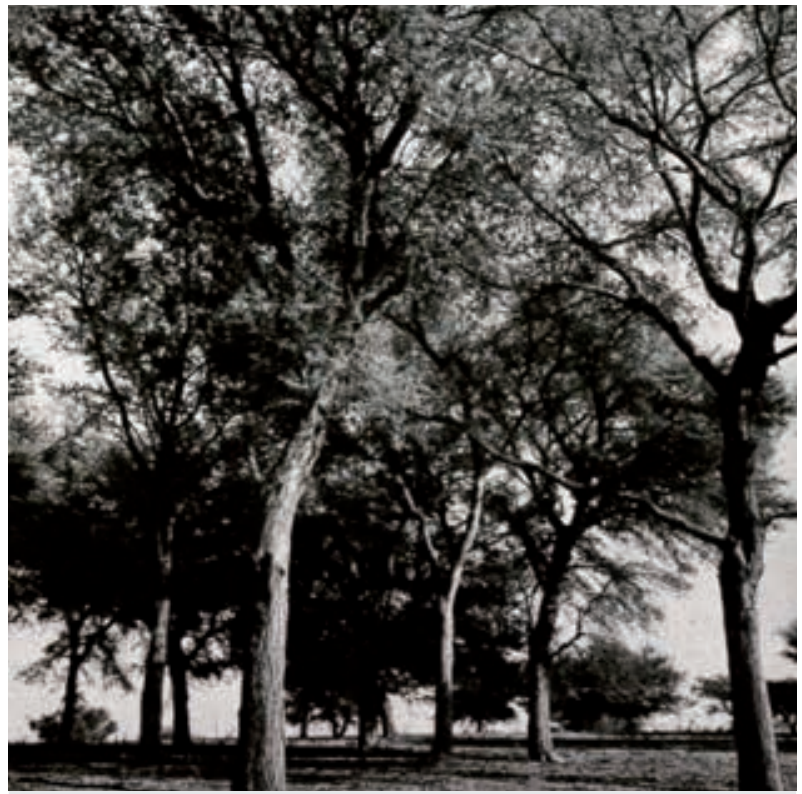

Photo 4.

Faidherbia albida (Delile) A. Chev. (1934) growing as a shade tree in a crop field.

Photo L. Bégué. 
F. C. Hummel, at the Imperial Forestry Institute in Oxford, studied samples taken in Ghana by A. Foggie from March 1944 to March 1945. The trees studied were Khaya grandifoliola C. DC., a large leaved African mahogany, and Entandrophragma angolense (Welw.) C. DC., a species of tiama.

The method involved making careful periodical measurements of the circumference of the tree at a specific height, over one year. At each measurement date, a sample of wood with its bark was taken at a different height for microscopic examination of the progress of wood formation.

The author was not able to deduce from this a way of recognising periodic growth rings in the African mahogany. With the tiama, he found that a continuous line of parenchyma coincided with a period of cambium dormancy. The dormancy period was short, from December to March, and the lines therefore corresponded to annual growth rings. Sometimes, when a double ring was apparent, the second ring did not correspond to a pause in growth during the short dry season, but rather to a second initial growth spurt.

Counting years thus seemed possible for tiama, except when the growth layers were too narrow to be distinguished from double growth rings.

R. G Lowe undertook a study in Nigeria on tree rings in samba wood (Triplochiton scleroxylon K. Schum.), presenting the preliminary results in 1961: the rings appear to be annual with wood formation ceasing for about two months at the end of the dry season.

Finally, H. M. Tschinkel recently published a 1964-1965 study on Cordia alliodora (Ruíz \& Pav.) Oken in Costa Rica. 32 trees were felled, 23 of which were of known age and 9 of unknown age but individually measured since 1954. Almost all the rings found, some of which were very narrow, were true annual growth rings. The first rings, formed when the trees were very young, were indistinct. There were virtually no false rings. H. M. Tschinkel concluded that counting the age of Cordia alliodora (Ruíz \& Pav.) Oken from a cross-section cut at the base of the trunk is eminently possible, provided that care is taken with very narrow growth rings by cross-checking them with sections cut higher up in the tree, where the rings are more distinct.

\section{Difficulties with using growth rings in tropical wood}

A growth ring in a cross-section of a tree corresponds to an increment in tree growth, in other words to a layer of wood apparently produced during one growing season. It is called an "annual growth ring" when it corresponds to one year's growth.

Two problems need to be resolved: first, the growth rings have to be visible and individually discernible, from the first ring around the pith to the most recent just below the bark. If they are not clearly discernible, a way of making them stand out needs to be found.

Secondly, if the rings are distinct, it must be determined whether they are formed annually or otherwise. Obviously the second question cannot be addressed unless the first has been satisfactorily resolved.
Distinguishing growth rings in a cross-section of wood requires material means of preparation and investigations based on prior knowledge of the structure of the wood. This is the "static" aspect of our study.

Determining the periodicity of growth ring formation is the "dynamic" aspect. This requires accurate field observations of the trees over several years, in the knowledge that the accuracy of the information depends on the methods designed to undertake the observations.

We will now successively examine these two aspects of the study of growth rings.

\section{PART ONE: VISIBILITY OF GROWTH RINGS}

Two factors determine the visibility of growth rings: their nature, which depends on the constituent elements of the wood, and the process used to examine the cross-section of the tree. The examination process chosen may depend in part on the nature of the growth rings.

\section{Nature of the growth rings}

Two examples of well-known wood from temperate regions will show how growth rings that are equally visible can differ in nature. In oaks, they mainly form a continuous porous zone made up of large vessels that mark the limit of a growth layer. In pines, as in other conifers, there are no pores: the growth rings appear only as an abrupt variation in the thickness of the fibre walls (tracheids).

We will now briefly review the constituent elements of wood that have a role in the aspect of growth rings in tropical timber.

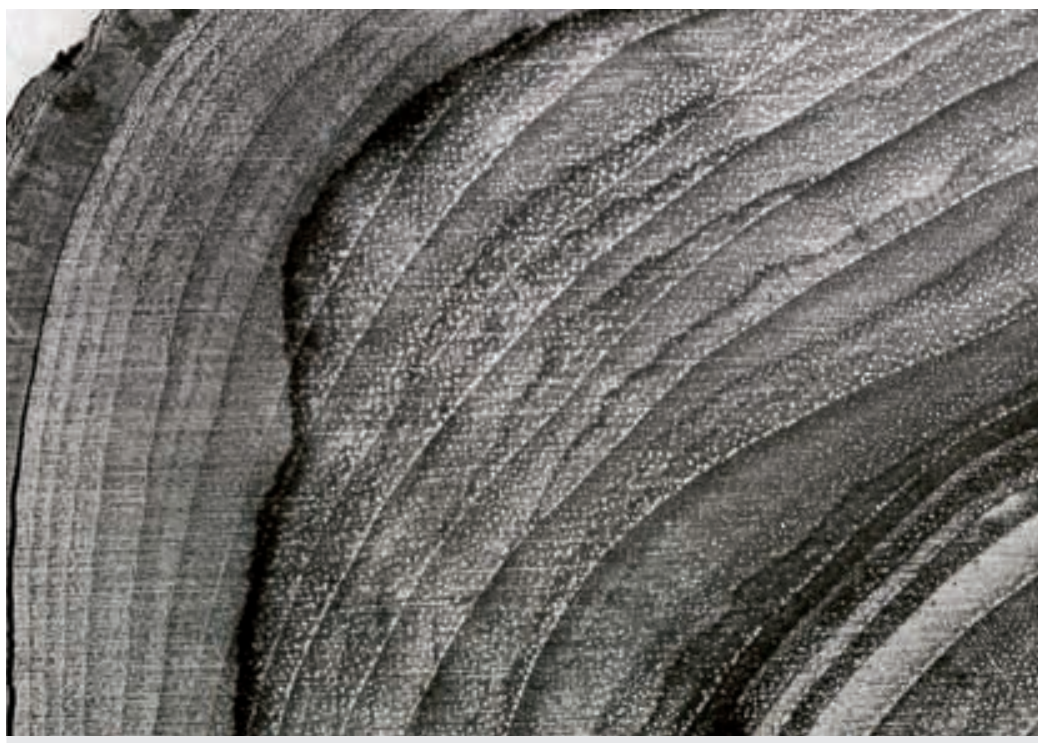

Photo 5.

Teak (Tectona grandis L. f.): the dark-coloured veins are separate from the light-coloured growth rings.

Photo A. Châtelain. 


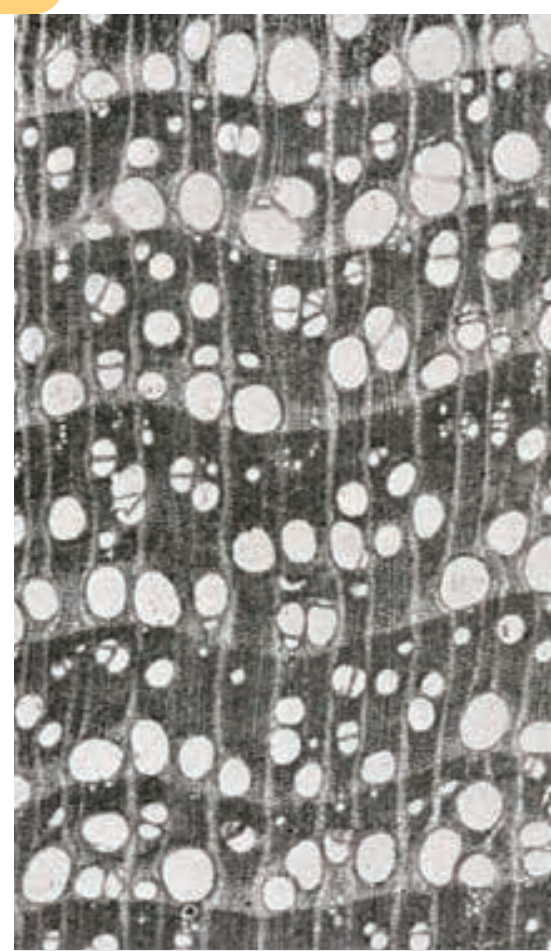

Photo 6.

Teak (Tectona grandis L. f.), cross-section magnified x14: porous zones accompanied by an initial layer of parenchyma. The growth rings here are very narrow. Photo J. Paquis.

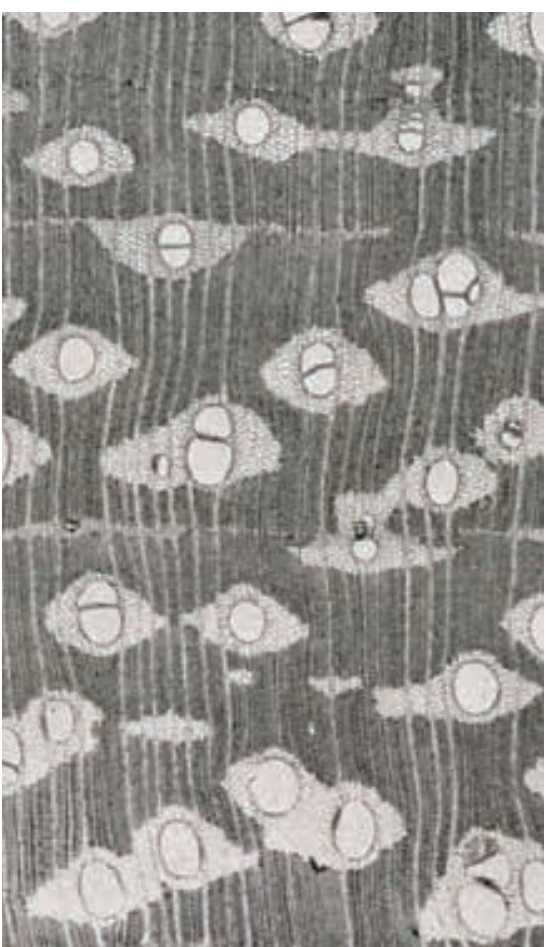

Photo 7.

Apa (Afzelia bipindensis Harms), cross-section magnified $\times 14$ : growth rings bordered by a tangential line of parenchyma.

Photo J. Paquis.

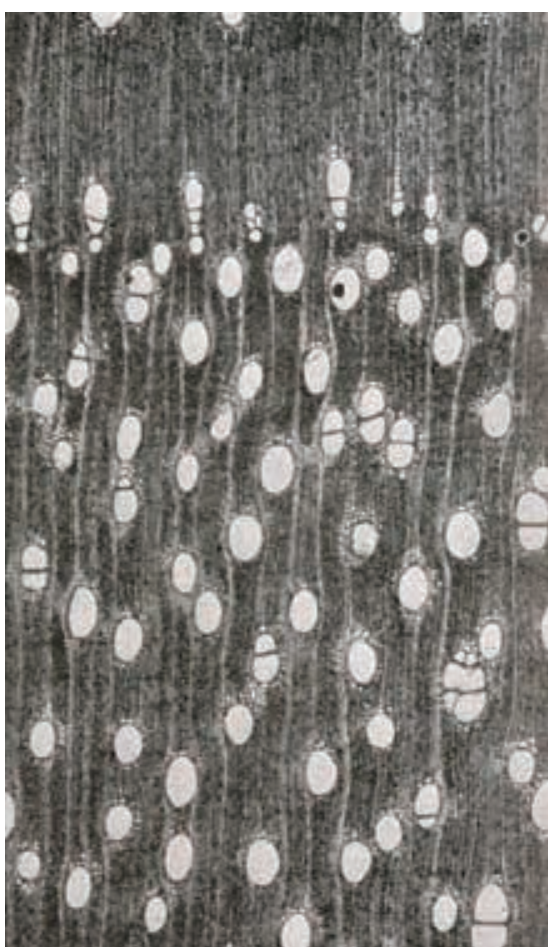

Photo 8.

Framire (Terminalia ivorensis A. Chev.), cross-section magnified $\mathrm{x} 14$ : the growth rings appear as a zone with no vessels bordered by very small vessels.

Photo J. Paquis.

\section{Coloured veins}

Coloured veins are the most salient aspect in some types of wood and give a superficial impression of being easy to count. In fact, highly coloured veins are rarely linked to growth layers. They form when sapwood is transformed into heartwood, i.e. with duramen formation, and appear to represent irregularities in the progress of this chemical transformation. They are not found in sapwood and if the growth layers are defined clearly enough by the structural components of the wood, it is usually possible to check that the growth rings are not veins, as the latter are more irregular and less numerous.

However, some less highly coloured and very regular veins correspond to variations in the structure of the wood, which we shall now discuss.

\section{Vessels}

Generally referred to as pores when seen in a cross-section of wood, the combination of their size and number can play a role by making the wood seem more or less "porous". Often, after a period of inactivity of the tree, the first woody zone formed is fairly porous, with larger vessels than in the remainder of the growth ring. This phenomenon is seen at its maximum in what is known as porous zone wood, but this is very rare in tropical species. Teak (Tectona grandis L. f.) has a more or less distinct semi-porous zone, with a discontinuous a line of large vessels along its outer limit. This characteristic is also clear in Cedrela spp. In some tropical species, although they have no true porous zone, the vessels in the early wood are larger ${ }^{5}$.

In trees that have become very slow growing, due to age or unfavourable circumstances, the accumulation of very narrow growth layers produces an abnormal proportion of large vessels, giving the wood a "hollow" aspect. This is the case with Faidherbia albida (Delile) A. Chev. (1934) in the Sudanian zone when their branches have been severely reduced by herders seeking fodder.

In most tropical wood, the variation in the size of pores in a given growth layer is very slight. However, very small vessels are sometimes found around the outer limit of a growth layer. These alone would not produce an obvious growth ring, but they can help to assess whether a ring apparently formed by other characters is actually present.

5. In the layer of wood formed during a growing season, "early wood" is the wood formed initially and "late wood" is the subsequent wood, and therefore beyond the early wood. In wood from temperate regions, these are mainly referred to as spring and summer wood, but these terms are obviously not suited to tropical wood. 


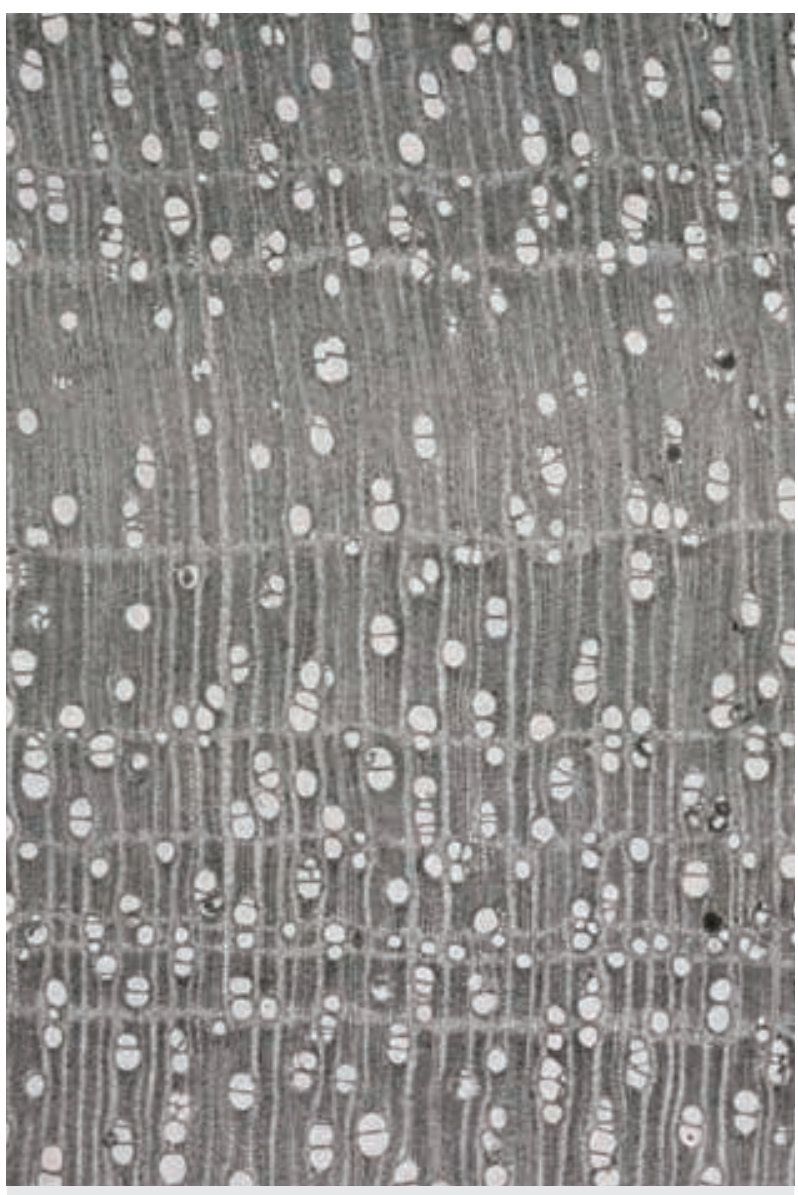

Photo 9.

American mahogany (Swietenia macrophylla King), cross-section magnified $\mathrm{x}$ 10: growth rings bordered by a line of parenchyma. Photo J. Paquis.

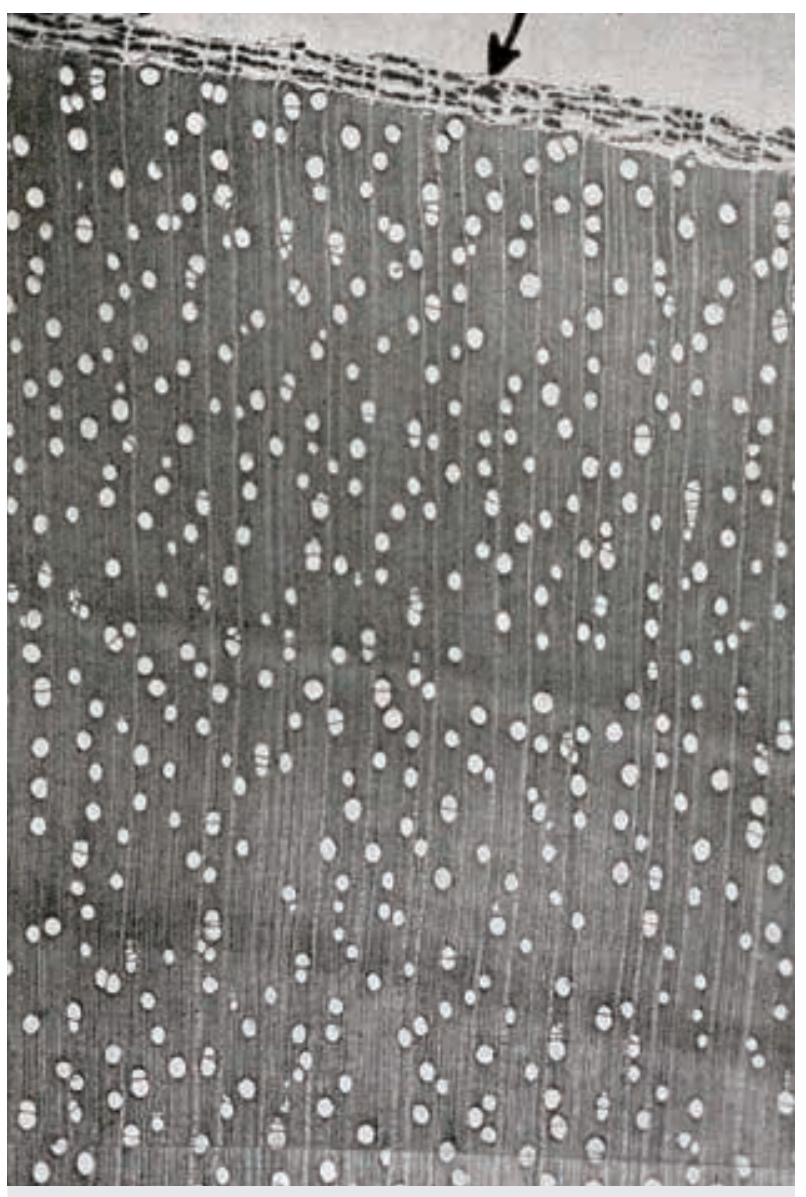

Photo 10.

Okoume (Aucoumea klaineana Pierre), cross-section magnified $\mathrm{X}$ 10: growth rings appearing solely as a variation in the density of the fibrous tissue. Top: a fragment of bark.

Photo J. Paquis.

\section{Parenchyma $^{6}$}

A thin, continuous diagonal line bordering a growth layer is frequently found in tropical wood and is also one of the most reliable markers of a growth ring. The only disadvantage is that the line is too narrow to be discernible, except on well-prepared wood and with a magnifying glass. It is this type of line that was found by F. C. Hummel to mark the outer limit of annual growth rings in a tiama (Entandrophragma angolense (Welw.) C. DC.) and which is found in other species of the same family, as well as in many leguminous species such as Doussié (Afzelia sp.), Sau (Isoberlinia doka Craib \& Stapf) and others.

In teak, the semi-porous zone already mentioned appears with a line of parenchyma, which in some cases is wide

6. For the benefit of non-specialists in tree anatomy, "parenchyma" refers to soft tissues with thin cell walls, which are usually light in colour in a cross-section of the wood. They may form "sleeves" around the pores or bands at a tangent to the bark. enough to enclose large pores. Sometimes, on the other hand, there is no porous zone and the line of parenchyma appears to replace it.

Periodicity in the width and spacing of rings is also found in the parenchyma-rich wood that occurs in numerous tangential layers alternating with layers of fibre in the same growth ring. For example, wide and slightly curving or even discontinuous and irregular bands can be seen in early wood, while in later wood, the bands are narrower, straighter and closer together. Overall, to the naked eye, the aspect produced is one of variation in texture and colour. This is a frequent trait in many leguminous species such as Faidherbia albida (Delile) A. Chev. (1934), Senna siamea (Lam.) H.S. Irwin \& Barneby, Pterocarpus erinaceus Poir. and many other families.

\section{Fibres}

These make up the basic fabric of the wood in which the other constituents - vessels, parenchyma, radii - appear to be enclosed. In a cross-section, fibres can only be seen 


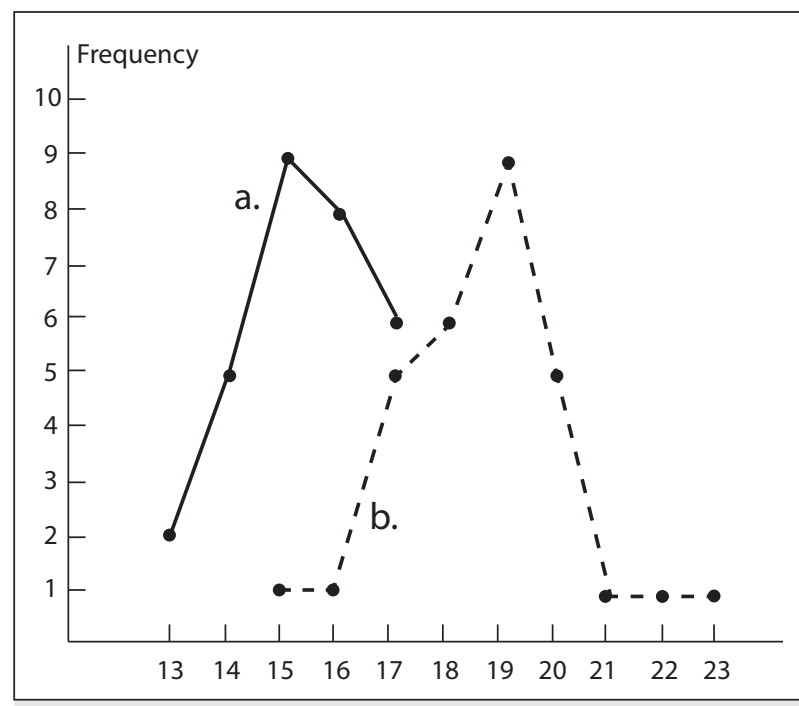

Figure 1.

Okoume - comparative frequency of the number of fibres counted radially over $250 \mu$ in a light-coloured layer (a) and in a dark coloured layer (b), showing that the fibres are denser in the dark layers.

individually when magnified at least 20 times, but they have considerable influence on the aspect of the wood due to the combination of their individual characters.

Flattened fibres in late wood are a frequent trait in tropical wood, although less so than in wood from temperate regions. With or without a thickened outer wall, fibres with a smaller radius form a tissue with a smaller proportion of cavities; the whole appears darker, and is denser, than the fibrous tissue of early wood.

This trait is in more evidence in wood where no parenchyma is apparent. It may be limited to some flattened cells forming a thin line, as in Lannea, which may be confused at low magnification with a line of parenchyma and which often has abundant compartmentalised fibres. But there may also be a wider area of radially shortened fibres, usually with a very gradual transition to wider fibres. Okoume (Aucoumea klaineana Pierre) and African mahogany (Khaya ivorensis A. Chev.) are two examples.

In Okoume wood, shown here in a micro-photograph, darker layers can be clearly seen. Because of the importance of this species to foresters and the lack of other ways of discerning the outer limits of growth rings, we attempted to identify the nature of the difference between the dark and light wood. This cannot be done with any certainty from a qualitative appraisal alone: the greater the magnification to observe cells in detail, the more blurred the difference becomes between dark and light zones, to the point where no outer limit can be discerned at all.

We found a significant difference in the radial diameter of the fibres (figure 1) and no appreciable difference in the thickness of the outer walls. There may also be a chemical difference, such as more pronounced lignification of the late wood.

\section{Complex growth rings}

The above study somewhat artificially isolates factors that usually combine in wood to form growth rings. A typical growth ring in framire wood (Terminalia ivorensis A. Chev.) begins with layer of fibrous tissue with no pores (early wood). Much wider pores then appear, which then become smaller towards the late wood, where the final layer is a narrow layer of dense fibrous tissue with a few very small pores. The parenchyma only plays a secondary role by underscoring the pores that it more or less encloses in a sheath. In limba wood (Terminalia superba Engl. \& Diels), on the other hand, although it does share the same traits to some extent, the parenchyma plays a predominant role through the lines it forms between pores, which are thicker and more continuous in the late wood than in the early wood.

\section{Irregularity of growth rings in tropical wood:}

The structure of the growth rings, formed as we have seen by a simple or more complex pattern formed by the tissues, is not absolutely identical in the same species, or not always, and this is one source of problems in their use.

Even the simplest and most reliable type, a thin and continuous line of parenchyma, is frequently problematical when it becomes a double line. F. C. Hummel had already noted this difficulty in the one Entandrophragma angolense (Welw.) C. DC. he observed. It is easy to think that a double line is not a problem when it separates wide growth layers, but if these are very narrow and of the same width as the wood between the double line, counting the actual rings can prove very difficult.

On some teak cross sections, it can be seen that the porous zone is well-defined in some growth rings and virtually absent or more or less distinct in others, when it appears to be replaced by a band of parenchyma. It would be worth investigating whether the growth rings without a porous zone are as "real" as the others, in other words formed over the same period.

In species where the growth rings are due to variations in the density of fibres or in the number and regularity of bands of parenchyma, some growth rings can be mirror images of each other, with the late wood in one having the same aspect as the early wood in another, while with some growth layers, there may be no appreciable difference between the early and late wood so that they are separated from the next layer only by an abrupt change in the aspect of the parenchyma.

We could describe an indefinite number of such irregularities in the aspect of growth rings, which arise from the more general phenomenon of variations in the structure of tropical wood.

We should add the occasional presence, in some species, of false borders that are due to incidents in the life of the tree (forest fire, damage to the crown, insect attacks, etc.), and which we refer to as trauma bands for that reason: in African mahogany, the only tangential lines of parenchyma are trauma bands, some of which may appear to mark growth rings. Gum channels often appear in these bands and help to recognise them for what they are. 


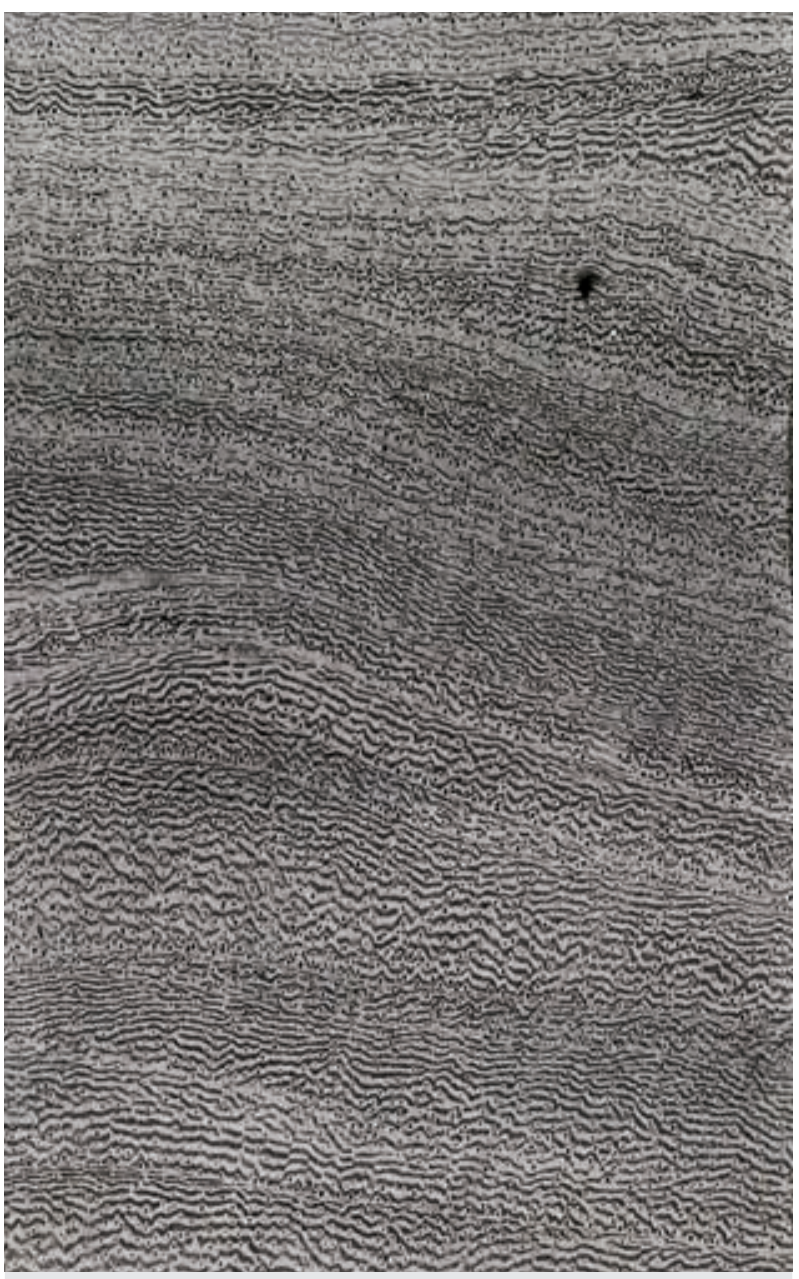

Photo 11.

Faidherbia albida (Delile) A. Chev. (1934). Finely sanded cross section (magnified $\times 2$ ): growth rings distinguished by a change in the pattern of the parenchyma and in the width of vessels. Top: Very narrow growth ring intervals. Photo J. Paquis.

Finally, as a very general rule, the first growth rings around the pith are less distinct than later rings.

These difficulties should not be seen as overwhelming: simply, in most cases, one should not expect counting growth rings in a cross-section of a tree to be easy.

Previous knowledge of the best definition of growth ring borders for the species in question is essential, so that it will first be necessary to find the best techniques to distinguish growth rings as well as possible. This is the subject of our next section.

\section{Reading Growth Rings}

With saw-wood, it is virtually impossible to read growth rings at the cut end whatever the type of saw used (chainsaw, cross-cut saw, etc.).

\section{Mechanical treatment of cut surfaces}

A section of green wood can be prepared quite well with a very sharp-bladed plane, but this is not often possible.

Usually, the cross section to be examined will not be fresh enough at the time of preparation and the best technique is to make a new smooth cut to remove the ridges and furrows left by the saw. The surface should then be carefully sanded, first with medium grain sandpaper and then with a very fine grain.

Sanding is done on a surface, whether by hand or by any common type of sander. The result is a certain amount of blurring by the wood particles that are abraded away and pulled across the surface. To prevent this blurring effect, the growth ring research laboratory at the University of Arizona has developed a machine that treats the wood like a plane rather than a sander, by the mean of a cylinder generatring lines. This method seems to produce excellent results, but requires a specially constructed machine.

In sapwood, which is whitish, growth rings are sometimes more clearly seen than in perfect wood with coloured veins, provided there is no blue staining. This can blur growth rings considerably, especially in young trees which have a large proportion of sapwood.

With many species, growth rings can best be seen by placing a finely sanded cross-section under running water, so that the surfaces are observed under a thin layer of water. This can subsequently alter the aspect of the wood ring if it is to be preserved, but at the time of observation, the greater contrast produced between the tissues makes it much easier to discern individual growth rings. A trial run should be made for each new species studied.

With very light-coloured wood, it is also possible, although we have not tried to do this, to use a dye diluted in water. A. E. Patterson advises the use of phloroglucinol with acetic acid and observation under ultraviolet light, while D. Holz suggests soaking the wood in a dilute solution of sodium or potassium.

Depending on the type of growth rings, the sanded surface can be examined in different ways, with the naked eye or using a magnifying glass or binocular magnifier. However, experience has shown that the naked eye is rarely sufficient. In practice, accurate observation requires a wide-angle binocular apparatus with $\times 6$ to $\times 10$ magnification, although this is not absolutely necessary when the growth rings are very wide or very obvious.

Even on a very finely sanded surface, there may be doubts over a very fine ring due to the presence of a thin line of parenchyma. In this case a curved razor blade can be used to make a shallow notch in the surface at this point, to aid identification from a very smooth cut.

\section{Corrosion}

Old logs lost during loading and washed up on beaches can show very clear growth rings when examined, for example in okoume wood from Gabon, where few growth rings are apparent in fresh logs. The layers of soft wood are abraded by seawater, and more probably by the sand churned up by the waves, so that the harder layers stand out clearly. 
This effect suggests that a similar result could be obtained with some kind of corrosive process. A jet of sandladen water could be considered, although it might be difficult to direct it closely enough to bring out narrow growth rings with no clear texture.

J. Kisser and J. Lehner reported a chemical process in 1951, which involves soaking well-sanded cross sections of dry wood in a bath of concentrated sulphuric acid. The trees in this case were conifers. The acid ate quickly into the thinwalled fibres and more slowly into those with thicker walls. The process could therefore be considered for wood where growth rings can be clearly seen on a cut surface. When tested with okoume from Gabon, the treatment produced a very clear relief after five hours, but the results were inadequate after two hours. Careful sanding is very important because any inadequately prepared zones produce irregular corrosion, so that the samples are not really usable.

The results seem somewhat rudimentary insofar as the variations in density that show up growth rings in wood are not pronounced in most tropical timber and because, as we shall see, the key to the question of using growth rings is the interpretation of subtleties.

We did not continue the tests with sulphuric acid because our attention was drawn to a different method more suited to indistinct growth rings of this type, involving x-ray images.

\section{X-ray analysis}

X-ray analysis is now well known in different disciplines concerning wood and has become a valuable tool for studies

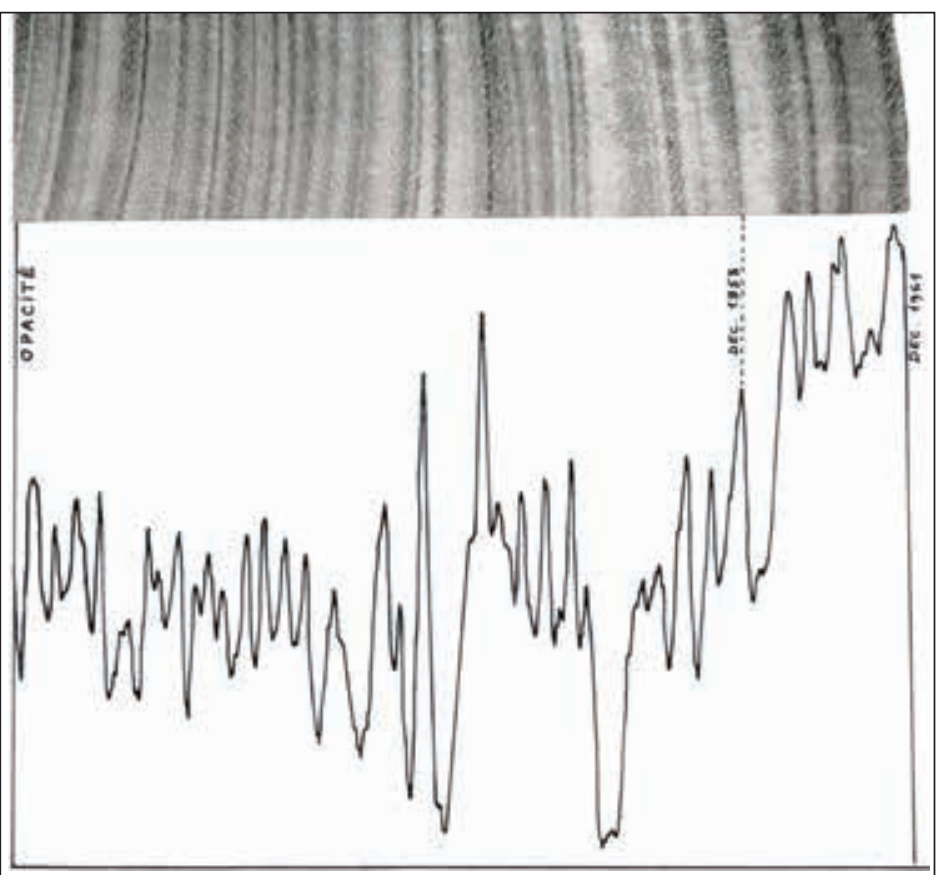

Photo 12.

Okoume. Positive image and densitometric profile of the same growth rings at essentially the same scale, from an x-ray image.

$\mathrm{X}$-ray image and plot: CNRF Nancy. of density and texture. Following the article published by Polge on a new method for determining the texture of wood - densitometric analysis of $\mathrm{x}$-ray images - we commissioned the National Forestry Research Centre in Nancy to apply the technique to different samples of tropical wood.

Two operations are required, the first being to take $x$-rays of the wood samples. These samples are small bars a few millimetres in thickness cut across the grain of the wood along a radius from the heartwood to the bark, and of any width along the tangent.

The $x$-ray images are taken with the sample placed directly on the photographic plate, with the x-ray source 2.50 $\mathrm{m}$ away to reduce the parallax effect. The voltage used has to be very low (soft x-rays) to obtain sufficient contrast between similar layers of wood and to reduce the grain of the image. In this case, a voltage of $25 \mathrm{Kw}$ was used, followed by $10 \mathrm{Kw}$ with a different machine. This requires long exposure times, of up to 2 hours.

\section{Radiographs}

Positive prints were then taken from the x-ray image. The quality of the images obtained is irregular, but the results are excellent overall. Growth rings that were not always clearly distinguishable when the wood was examined directly stand out clearly with many details becoming apparent. The denser zones are dark in colour and the soft wood zones are lighter. Even the pores are clearly visible as white dots; the strips of parenchyma, in iroko and azobe for example, also appear as light-coloured lines.

The main difficulty arises with an interlocked wood grain, where very distinct layers alternate with more indistinct layers in which the pores appear as lines instead of dots, or even disappear completely. This could be of secondary importance were it not for the influence of the inclination of fibres on the transparency of the wood to the x-rays, and thus on the opacity of the images of this zone, which modifies the interpretation of the outer limits of the growth ring.

There appears to be little value in these radiographs when the anatomy of the wood defines the growth rings quite distinctly. However, they could be of considerable value for studies of wood such as okoume, where only slight variations in density occur.

\section{Densitometry}

The optical density of an object is the decimal logarithm of opacity, in other words, the ratio of the intensity of the light received by the object to the intensity of the light passing through it:

$d=\log _{10} \mathrm{I}_{0} / \mathrm{I}$

The National Forestry Research Centre in Nancy has a micro-densitometer that measures light passing through a microscopic surface to plot it continuously on a graph, according to the logarithmic response, thus recording the optical density directly along a linear scale. Because the optical density of the image at a given point within the relatively narrow wavelength range used, and at a given point in the development of the image, is in inverse proportion to the density of the wood at the relevant point in the sample, the 
values plotted on the graph are linearly related to the density of the wood.

When the apparatus explores the image of a wood sample, the graph that results is a jagged line with the $X$ axis representing the progress of the exploration through the image and the $Y$ axis representing the variations in the density of the wood. The apparatus is very sensitive and records the smallest variations in the texture of the wood. In European timber, the minimum values correspond to spring wood and the maximum values to summer wood, thus allowing a very fine analysis of texture.

Any imaging errors are necessarily also plotted on the graph. For example, zones with an oblique grain may be recorded at a different intensity to zones with a very straight grain; indistinct areas then appear as small variations in amplitude.

A final difficulty for interpretation arises from the numerous cross sections of vessels. As these show up on the images as dots or light-coloured stripes, the exploratory movement of the light spot causes the graph to dip sharply downwards. The result is a hatched profile in which the narrow and abrupt dips representing the vessels are superimposed over the more sinuous line representing variations in texture. However, when the light spot was widened as far as possible, the graph was much clearer and seemed to have adequately handled the effects caused by the vessels.

Before developing this method further, we decided to wait for the results of studies currently under way in the field on the periodicity of wood formation in tree species for which the densitometric profiles could provide new material to interpret the $\mathrm{x}$-ray images examined.

The position may be summarised as follows: in tropical wood, growth rings are sometimes distinct and can be counted with the naked eye, provided that the narrower zones are checked with a magnifying glass; more frequently, growth rings in the ligneous surface demand careful examination through a magnifying glass; lastly, some growth rings that are indistinct, not apparent or even non-existent may be discernible, and hopefully countable, thanks to x-ray photography.

In Part 2, we will examine methods applied to determine the periodicity of growth ring formation, discussing these in the light of our initial results.

\section{PART TWO: PERIODICITY OF GROWTH RINGS}

\section{Study methods and initial results}

In Part 1, we described the presence and nature of growth rings in tropical wood and methods applied to make them visible and countable.

Since our aim is to obtain an estimation of the age of trees, we now need to investigate the rhythm of growth ring formation according to seasonal growth periods, in the hope of discovering a reliable relationship between the number of growth rings and the number of years in the life of a tree.

This second part describes the methods used for this purpose, which are illustrated and discussed in the light of the initial results obtained.

\section{Rhythm of the growth cycle and seasons}

In temperate zones, after a dormant period in winter when wood formation ceases, tree growth resumes from the spring through to autumn. A new layer of wood then forms. Typically, and depending on species, the early and late wood can be more or less easily distinguished. The latter is the outer and densest part of the year's layer of wood: it is usually darker in colour, forming a "ring" around the year's new growth.

Sometimes, if a period of drought occurs during the summer, a "false" growth ring may appear in the new wood layer, followed by further growth that forms the true late wood.

In a cross-section of a tree, each year's growth layer ends in a ring that clearly separates the dense late wood formed during the year from the softer or more porous early wood formed in the following year.

In broadleaved trees, the onset of winter meristem dormancy coincides with leaf fall, whose effect on wood formation as a physiological event thus combines with the effect of winter dormancy.

In tropical African countries, the year is also divided into seasons, but the climatic factor characterising them is humidity: there are rainy seasons and dry seasons. This is not the place to analyse the causes of the growth cycles that may emerge. Others have addressed this vast subject. In Tanganyika for example, S. B. Boaler found that the beginning and the end of growth in diameter in muninga trees (Pterocarpus angolensis DC.) are not directly related to water deficit during the growing period, even though short periods without rain cause interruptions in growth. In about a dozen forest species in Nigeria, E. Njoku also observed a time lag between growth activity (formation of new leaves) and onset of the rainy season. He conducted an interesting experiment showing the influence of slight variations in the duration of daylight on growth, and also suggests that relatively low nocturnal temperatures could play a role in the bud cycle. He also observed that dormancy in young trees is much less marked than in adult trees. This is an important factor accounting for the lack of clarity of early growth rings.

Elsewhere, in Costa Rica, L. Lojan found that growth in diameter in several deciduous species correlated with rainfall over the year, but not with detailed rainfall figures during the rainy season. In evergreen species, mainly eucalyptus, growth was negatively correlated with the duration of sunlight and had no correlation with rainfall. "The rhythm of growth appears to be governed more by genetic factors than by the effects of climatic factors. It is characterised in evergreen species by continuous growth that slows down during the dry season, and in deciduous species by a period of growth and a period of dormancy of almost equal duration".

Independently of the climatic or genetic factors to be considered, the rhythm of growth generally observed in Africa is roughly as follows:

Deciduous tree species. In savannah regions, and in some dense forest species, especially of the "deciduous" 


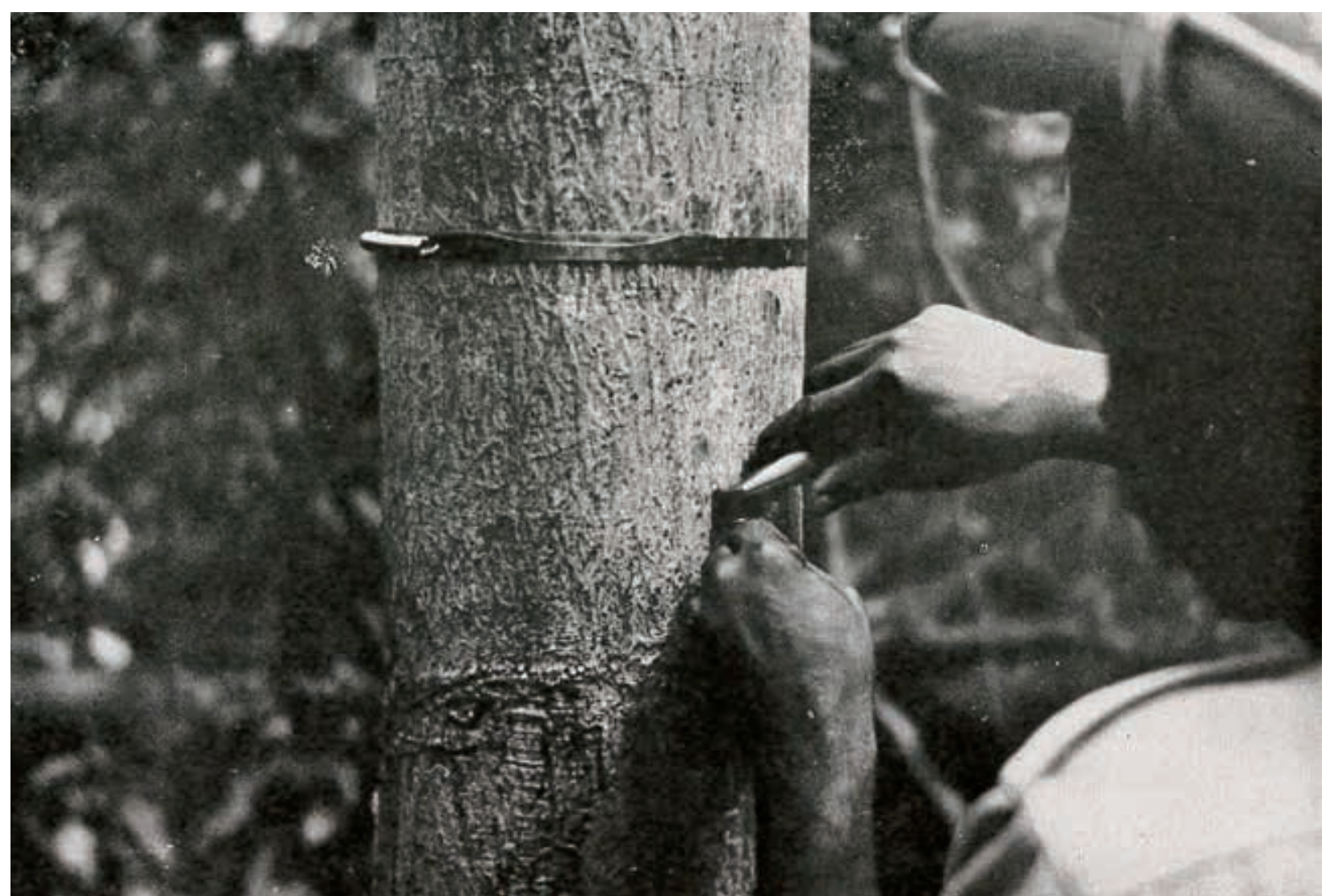

Photo 13.

Making the first mark on dendrometric tape placed on a samba tree (Triplochiton scleroxylon K. Schum.), Oumé, Côte d'Ivoire. Photo A. Mariaux.

type, trees lose all of their leaves, with new foliage appearing after a variable period. This occurs in the dry season, barring a few exceptions (Faidherbia albida (Delile) A. Chev. (1934) for example, which loses its leaves during the rainy season). Even in the Sudanian zone, new leaves appear in many species after a short leafless period, so that the trees appear green and fresh when the surrounding savannah is still drought stricken. However, bushfires can subsequently cause sudden and enduring leaf loss.

Evergreen species. New foliage appears gradually, either in a very diffuse manner or after an entire branch has lost its leaves.

This obviously suggests that regular growth in diameter is more likely in the first category, along with growth rings corresponding to each year.

\section{Periods of wood formation}

Based on the previous general and well-known indications on the growth rhythm of trees, we needed to choose methods of observation or experimentation that would enable in-depth investigations of the following points in tropical African tree species with sufficiently distinct growth rings:
- In which periods of the year does wood form, and in which periods is the cambium dormant?

- Does the dormancy period, if confirmed, correspond in a regular way to what is referred to as the outer limit of a growth ring?

- Does one growth ring marked by an outer limit form regularly each year?

- If the rhythm of growth is more complex, is it still possible to distinguish one year's growth in the wood?

\section{Cambium samples}

\section{Method}

There are few methods with which wood formation can be periodically monitored. The first we knew of and applied was the one used by Chowdhury for his studies at Dehra Dun, which involved periodically taking samples of cambium.

The purpose of this method is to make direct observations of the condition of the cambium zone in which new wood layers develop. 
The principle is very simple, as it involves removing a sample of wood with its bark, without separating the one from the other. A transversal thin section is then cut and dyed in two colours, so that it can be seen under the microscope whether the cambium is dormant or active. An active cambium is recognizable by its thickness, which gradually takes on the structure of normal wood in a zone where lignification is occurring.

This method raises two difficulties, although they do not diminish its value.

The first is that the task is somewhat painstaking. It is not easy to detach a piece of wood to which the bark adheres perfectly, especially at certain times of the year when the slightest involuntary movement can easily detach the bark. It is therefore difficult to demand frequent repetitions of the operation from those who are responsible for the continuity of investigations in the field, yet it has to be done at frequent intervals to identify the different phases clearly and without missing a period of dormancy.

The technique we adopted was as follows:

Using a fine-tooth saw, two parallel horizontal slits are cut into the wood, about $25 \mathrm{~mm}$ apart and deep enough to cut into the wood beneath the bark. This is easier with small trees than large trees.

With a sharp blade, two vertical incisions about $20 \mathrm{~mm}$ apart are made in the bark down to the wood, to form a rectangle with the saw cuts marking out the piece to be removed. These incisions should be made by applying light pressure rather than cutting sharply downwards. On each side, a second incision is made outside the rectangle, $1 \mathrm{~cm}$ away for example, to mark out a vertical slip of bark on each side. These slips are then prized out without damaging the bark on the sample. (Alternatively, a second saw cut can be made to prize out slips of bark above and below the sample.) This produces a clean cut around the bark sample, reducing the risks of detaching it to a minimum.

Using a hammer and a chisel inserted into the vertical slits, a rectangle of wood and bark of sufficient size, 1 to $2 \mathrm{~cm}$, can then be cut out.

Several leakproof beakers will be needed, filled with a formalin solution and numbered. The sample must be immediately immersed in the liquid so that it can be transported without drying or rotting to await laboratory testing.

For accurate observations, the cambium must be intact and easy to cut. However, the cambium is a very fragile tissue enclosed by two hard tissues, wood and bark, and the bark retracts and hardens considerably as it dries. It is only possible to make a clean cut when the sample is still fresh.

The second difficulty is as follows:

Cutting out the samples leaves a fairly serious wound on the trunk, so that it is difficult to take repeated samples from the same tree over any length of time without the risk of obtaining abnormal samples due to the trauma affecting wood growth. But if samples are taken from a different tree, observations may be distorted by differences in the activity of different individuals. This is probably the explanation for the uneven results obtained from savannah trees, where each sample was taken from a different tree.

\section{Applications}

In order to work with trees with a clear rhythm of growth, we began our observations in a savannah region in 1961.

To apply the method, we first chose to work with the forestry school at Dinderesso, near Bobo-Dioulasso in Upper Volta, where J. Parrat kindly agreed to provide us with the help we needed. Seven species were selected.

At the same time, a second series of samples ( 14 species) was organised in central Côte d'Ivoire, at the forestry research station in Kokondékro, near Bouaké, with the help of J. Lessent and A. Marcellesi. This region has a more complex climate and features patches of dense forest with many large deciduous species along with typical savannah species.

The choice of species was guided by the following considerations: they had to be locally common and typical, of average size, with bark adhering enough to the wood to prevent their separation when taking the samples, and with both wood and bark suited to cutting.

A two-month sampling interval was chosen, given that this was an initial trial, to see whether the cambium samples would allow cambium activity to be interpreted, and if so, to set a rough time limit to the operation without demanding too much from the volunteers.

The conclusions drawn from this trial series were follows:

- In some species, the thickness of the cambium varied depending on seasons. However, this was far from clear in all species, and to confirm or reject this hypothesis,
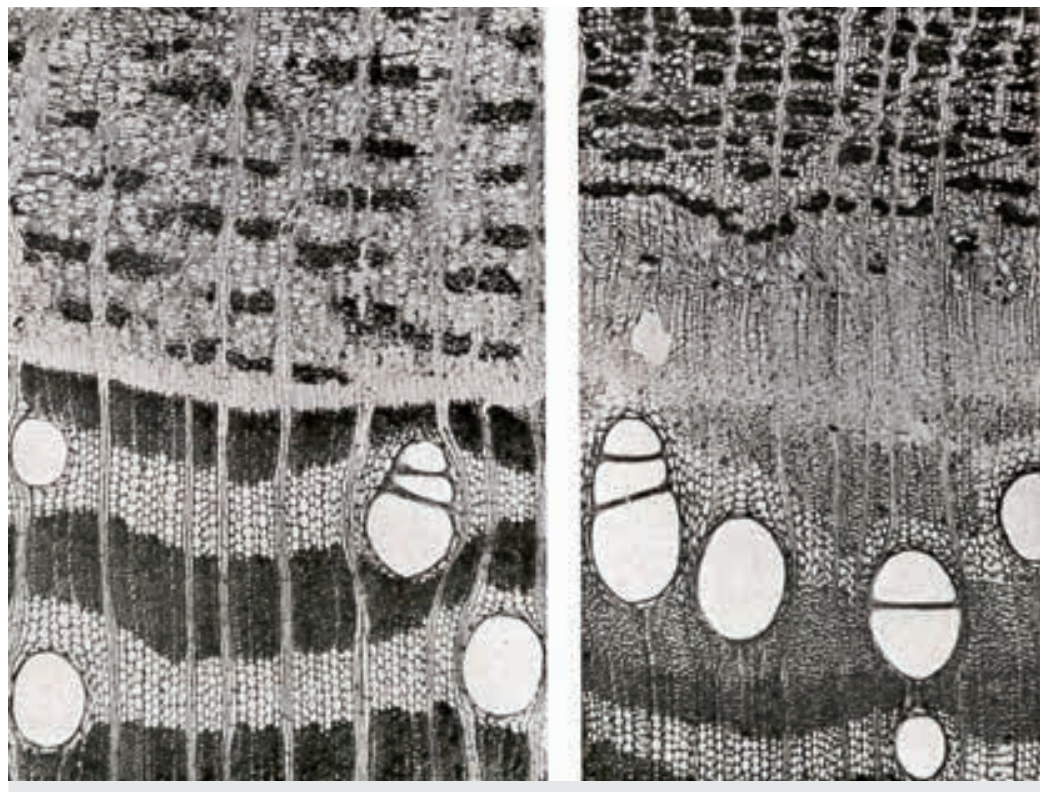

Photo 14.

Transversal sections of Senna siamea (Lam.) H.S. Irwin \& Barneby. The wood is in the lower part of the photographs and the inner bark (phloem) in the upper part. Left: dormant cambium. Right: active cambium and area of fragile wood in the process of differentiation.

Microphotographs, J. Paquis. 


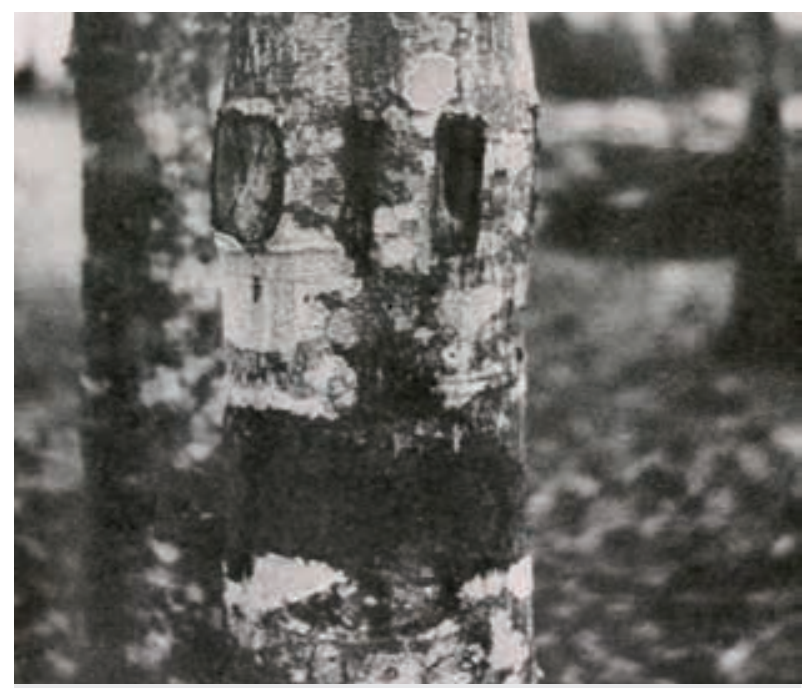

Photo 15.

A Senna siamea (Lam.) H.S. Irwin \& Barneby bole showing traces of the marks made periodically in 1961-1962 (Bouaké, Côte d'Ivoire), November 1963.

Photo A. Mariaux.

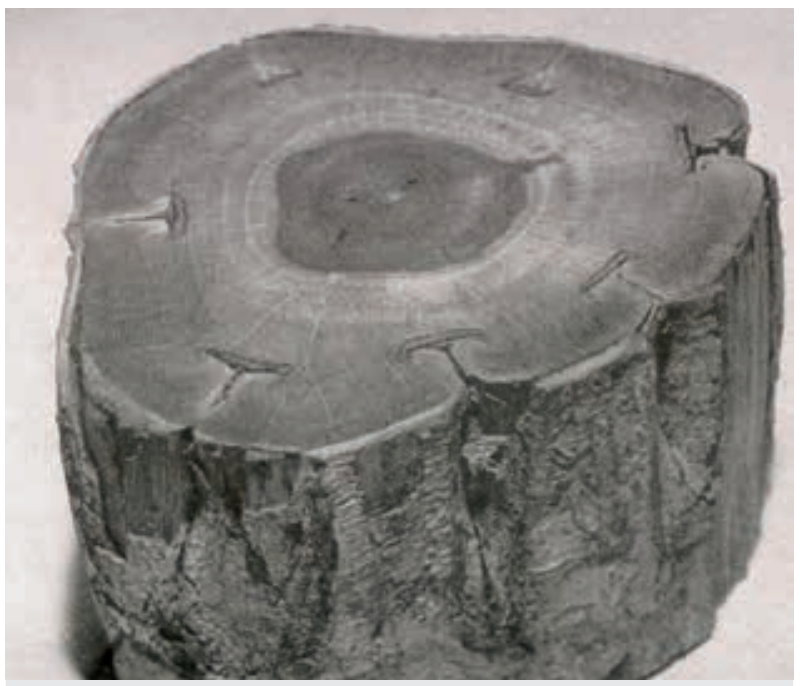

Photo 16.

A section of the trunk of the same tree seen from the same side, and showing scars from the periodic marking.

Photo A. Châtelain.

Table I.

Cambium activity and state of vegetation observed near Bobo Dioulasso, Upper Volta (Burkina Faso). The + and - signs indicate active cambium, gradual transformation into wood (+) or apparently dormant cambium with a clear outer limit (-). Two signs together ( \pm ) indicate a doubt, possibly at the beginning or end of activity. The state of the foliage is also shown, as normal (F), young (f), falling (\#) or absent $\left(^{\circ}\right)$.

\begin{tabular}{|c|c|c|c|c|c|c|c|}
\hline & $\begin{array}{l}\text { Oct. 27th } \\
1961\end{array}$ & $\begin{array}{l}\text { Feb. 1st } \\
1962\end{array}$ & $\begin{array}{l}\text { Apr. 2nde } \\
1962\end{array}$ & $\begin{array}{l}\text { Jun. 4th } \\
1962\end{array}$ & $\begin{array}{l}\text { Aug. 2nde } \\
1962\end{array}$ & $\begin{array}{l}\text { Oct. } 3 \text { rd } \\
1962\end{array}$ & $\begin{array}{c}\text { Dec 4th } \\
1962\end{array}$ \\
\hline Ficus dicranostyla Mildbr. & $\begin{array}{l} \pm \\
F\end{array}$ & $\begin{array}{l}+ \\
\#\end{array}$ & $\bar{F}$ & $\begin{array}{l}+ \\
F\end{array}$ & + & $\begin{array}{l} \pm \\
F\end{array}$ & $\bar{F}$ \\
\hline $\begin{array}{l}\text { Terminalia laxiflora Engl. } \\
\text { \& Diels }\end{array}$ & $\begin{array}{l} \pm \\
F\end{array}$ & $\overline{-}$ & - & $\bar{F}$ & + & $\begin{array}{l} \pm \\
F\end{array}$ & $\overline{\mathrm{F}}$ \\
\hline $\begin{array}{l}\text { Isoberlinia doka Craib } \\
\text { \& Stapf }\end{array}$ & $\overline{\mathrm{F}}$ & $\mathrm{F}$ & $\overline{\mathrm{F}}$ & + & + & $\begin{array}{l} \pm \\
F\end{array}$ & $\overline{\mathrm{F}}$ \\
\hline $\begin{array}{l}\text { Daniellia oliveri (Rolfe) } \\
\text { Hutch. \& Dalziel }\end{array}$ & $\begin{array}{l} \pm \\
F\end{array}$ & $\bar{f}$ & $\bar{F}$ & + & $\begin{array}{l} \pm \\
F\end{array}$ & $\begin{array}{l} \pm \\
F\end{array}$ & $\overline{\mathrm{F}}$ \\
\hline $\begin{array}{l}\text { Faidherbia albida (Delile) } \\
\text { A. Chev. (1934) }\end{array}$ & $\bar{f}$ & + & $\begin{array}{l}+ \\
F\end{array}$ & $\overline{-}$ & $\bar{\circ}$ & + & + \\
\hline $\begin{array}{l}\text { Senna siamea (Lam.) } \\
\text { H.S. Irwin \& Barneby } \\
\text { (introduced) }\end{array}$ & $\begin{array}{l}+ \\
F\end{array}$ & $\overline{\mathrm{F}}$ & $\overline{\mathrm{F}}$ & $\overline{\mathrm{F}}$ & $\begin{array}{l}+ \\
\mathrm{F}\end{array}$ & $\begin{array}{l}+ \\
F\end{array}$ & $\overline{\mathrm{F}}$ \\
\hline $\begin{array}{l}\text { Azadirachta indica } \\
\text { A. Juss. (introduced) }\end{array}$ & $\begin{array}{l} \pm \\
F\end{array}$ & $\overline{\mathrm{F}}$ & $\overline{\mathrm{F}}$ & $\overline{\mathrm{F}}$ & $\begin{array}{l}+ \\
F\end{array}$ & $\overline{\mathrm{F}}$ & $\begin{array}{l} \pm \\
F\end{array}$ \\
\hline
\end{tabular}


the boundary between the undifferentiated cells of the cambium and the young phloem cells would need to be more clearly discerned.

- A gradual or abrupt transformation of the cambium into word seems to be the best indication of cambium activity. During active periods, cells can be seen at every growth stage from the cambium base to wellformed and normally lignified wood. During dormant periods, undifferentiated cambium cells immediately follow wood cells of normal size and shape.

- Lignification, as appraised from the colour of the tissues, takes place once the cells are fully developed. This can occur after some considerable time and the process may come to an end a long time after the boundary between the wood and the cambium has become clearly defined.

- In wood with numerous bands of parenchyma, it is more difficult to observe where the cambium ends due to the similarity between the parenchyma and cells in the process of differentiation.

The results are given in tables I \& II, which are necessarily schematic and therefore do not reflect every nuance, where the + and - signs indicate active cambium, gradual transformation into wood (+) or apparently dormant cambium with a clear outer limit $(-)$. Two signs together indicate a doubt, possibly at the beginning or end of activity. The state of the

Table II.

Cambium activity and state of vegetation observed near Bouaké, Côte d'Ivoire.

The + and - signs indicate active cambium, gradual transformation into wood (+) or apparently dormant cambium with a clear outer limit (-). Two signs together ( \pm ) indicate a doubt, possibly at the beginning or end of activity. The state of the foliage is also shown, as normal (F), young (f), falling (\#) or absent $\left(^{\circ}\right)$.

\begin{tabular}{|c|c|c|c|c|c|c|}
\hline & $\begin{array}{l}\text { Oct. 14th } \\
1961\end{array}$ & $\begin{array}{c}\text { Dec. 15th } \\
1961\end{array}$ & $\begin{array}{c}\text { Feb. 19th } \\
1962\end{array}$ & $\begin{array}{c}\text { Apr. 16th } \\
1962\end{array}$ & $\begin{array}{c}\text { Jun. 15th } \\
1962\end{array}$ & $\begin{array}{c}\text { Aug. 16th } \\
1962\end{array}$ \\
\hline \multicolumn{7}{|l|}{ SAVANNAH SPECIES } \\
\hline Lannea acida & $\bar{\circ}$ & $\bar{\circ}$ & $\bar{\circ}$ & $\overline{\mathrm{F}}$ & $\overline{\mathrm{F}}$ & $\begin{array}{l}+ \\
\#\end{array}$ \\
\hline $\begin{array}{l}\text { Terminalia schimperiana } \\
\text { Hochst. }\end{array}$ & $\bar{F}$ & $\bar{\circ}$ & - & - & + & $\bar{F}$ \\
\hline Afzelia africana Sm. ex Pers. & $\begin{array}{l} \pm \\
\mathrm{F}\end{array}$ & - & - & $\overline{\mathrm{F}}$ & + & + \\
\hline $\begin{array}{l}\text { Daniellia oliveri (Rolfe) Hutch. } \\
\text { \& Dalziel }\end{array}$ & $\begin{array}{l} \pm \\
F\end{array}$ & $\overline{-}$ & - & $\bar{F}$ & $\overline{\mathrm{F}}$ & $\begin{array}{l} \pm \\
F\end{array}$ \\
\hline $\begin{array}{l}\text { Parkia biglobosa (Jacq.) } \\
\text { R. Br. ex G. Don }\end{array}$ & + & $\overline{\mathrm{F}}$ & - & $\bar{F}$ & $\begin{array}{l}+ \\
\mathrm{F}\end{array}$ & $\bar{F}$ \\
\hline Ficus dicranostyla Mildbr. & $\overline{\mathrm{F}}$ & $\overline{\mathrm{F}}$ & - & $\begin{array}{l} \pm \\
f\end{array}$ & + & $\begin{array}{l} \pm \\
F\end{array}$ \\
\hline $\begin{array}{l}\text { Sarcocephalus latifolius (Sm.) } \\
\text { E. A. Bruce }\end{array}$ & $\overline{\mathrm{F}}$ & $\overline{\mathrm{F}}$ & - & - & $\begin{array}{l}+ \\
\mathrm{F}\end{array}$ & $\begin{array}{l} \pm \\
F\end{array}$ \\
\hline Vitex doniana Sweet & $\bar{F}$ & - & $\bar{f}$ & $\bar{F}$ & $\bar{F}$ & $\bar{F}$ \\
\hline \multicolumn{7}{|l|}{ FOREST SPECIES } \\
\hline $\begin{array}{l}\text { Berlinia grandiflora (Vahl) } \\
\text { Hutch. \& Dalziel }\end{array}$ & $\overline{\mathrm{F}}$ & - & - & + & + & $\bar{F}$ \\
\hline $\begin{array}{l}\text { Anthocleista kerstingii } \\
\text { Gilg ex Volkens }\end{array}$ & + & $\begin{array}{l}+ \\
\#\end{array}$ & - & + & $\overline{\mathrm{F}}$ & $\bar{F}$ \\
\hline Uapaca togoensis Pax & $\begin{array}{l} \pm \\
\mathrm{F}\end{array}$ & $\begin{array}{l} \pm \\
\mathrm{F}\end{array}$ & - & $F$ & $\overline{\mathrm{F}}$ & $\begin{array}{l}+ \\
\mathrm{F}\end{array}$ \\
\hline Ceiba pentandra (L.) Gaertn. & $\begin{array}{l} \pm \\
\mathrm{F}\end{array}$ & \# & - & - & + & $\begin{array}{l}+ \\
\mathrm{F}\end{array}$ \\
\hline $\begin{array}{l}\text { Antiaris toxicaria var. africana } \\
\text { Scott-Elliot ex A. Chev. }\end{array}$ & $\begin{array}{l}+ \\
\mathrm{F}\end{array}$ & - & - & $\overline{\mathrm{F}}$ & $\overline{\mathrm{F}}$ & $\begin{array}{l}+ \\
F\end{array}$ \\
\hline $\begin{array}{l}\text { Senna siamea (Lam.) H.S. Irwin } \\
\text { \& Barneby (introduced) }\end{array}$ & - & - & - & + & $\begin{array}{l}+ \\
\mathrm{F}\end{array}$ & $\begin{array}{l} \pm \\
F\end{array}$ \\
\hline
\end{tabular}


foliage is also shown, as normal (F), young (f), falling (\#) or absent $\left(^{\circ}\right)$.

We stress here that full information on the formation of growth layers should not be expected from these tables, because the sampling intervals were too long. However, there is no doubt that by taking the necessary measures, in other words repeated sampling from a sufficient number of trees, it is possible to discern the periods of cambium activity very accurately. Our modest attempt already shows that of the 132 samples examined, only 19 raised any doubts as to whether the cambium was dormant or active. The dates when these doubtful samples were taken were often at the beginning of the active season, and especially at the end, which suggests that these are transitional states, which would have been confirmed by other samples taken a little earlier or a little later.

Overall, it may at least be said that none of the species investigated showed continuous activity. In West Africa, except for Acacia albida, which grows counter-seasonally, trees generally enter a period of dormancy around February and their activity is at its maximum around August (a little earlier in some cases, a little later in others).

If we assume that with more samples taken from the same species, we would have full knowledge of the rhythm of cambium activity, we would still not have achieved our goal. Although we observed a single period of wood formation during the year and although it is very likely that the wood formed corresponds to what is referred to a growth layer, proof is still needed.

When thin sections from the cambium samples are examined, growth rings can be discerned in the wood, at least if enough wood has been kept, with the outer ring located not far from the cambium. When the ring is distinct, it can be seen that at the start of cambial activity in successive samples, the cambial region separates from the ring and moves gradually away from it. But it is obvious that from the same tree needs to be frequently sampled to make sure that the ring, which is increasingly distant from the cambium, is still the same and that other rings do not form one after the other during the growing season, an uncertainty that increases when the ring is not clearly defined in a fragment of the section. A further source of difficulty is that, as we have said, the samples must not be taken too close to each other on the tree. There is therefore a risk of taking samples from areas growing at different rates, so that the distance between the cambium and the previous growth ring cannot be compared between samples.

This problem can be overcome by applying the following method.

\section{Marking the wood by cutting into the bark}

In a discussion with R. Catinot in December 1958, while observing a young okoume in Gabon, during the first attempt to resolve the problem of "dating" growth rings, we thought of the marks made on trees by hikers, which are sometimes found much later, deep in the wood, when the timber is sawn up. This will occur if the cut made into the bark reached the cambium. In the small area wounded by the cut, wood will not form until the cambial region heals when a callus forms around the wound. The result is a scar imprinted in the wood at exactly the spot occupied by the cambial tissue at the time of the cut.

In the bark of our okoume, which was about $30 \mathrm{~cm}$ in diameter, we therefore cut out a "window" about the size of a postage stamp, deep enough to reach the wood and making sure that we removed all of the phloem.

Three years later, in December 1961, the tree was felled and a disc was cut from the trunk bearing the mark that could still be seen on the bark. A scar was clearly evident in the cross section of the trunk cut from the area where the mark had been made, although it was well covered by a callus with no necrosis present (microphotograph above).

The section prepared for the microphotograph of the okoume in Part One of this article was cut close to this mark. The scar was exactly on the dark line shown by the arrow. There are three annual growth layers between this spot and the bark (December 1958 to December 1961).

Anticipating on the encouraging result of this test, we began to make a series of periodical marks in October 1961 ,

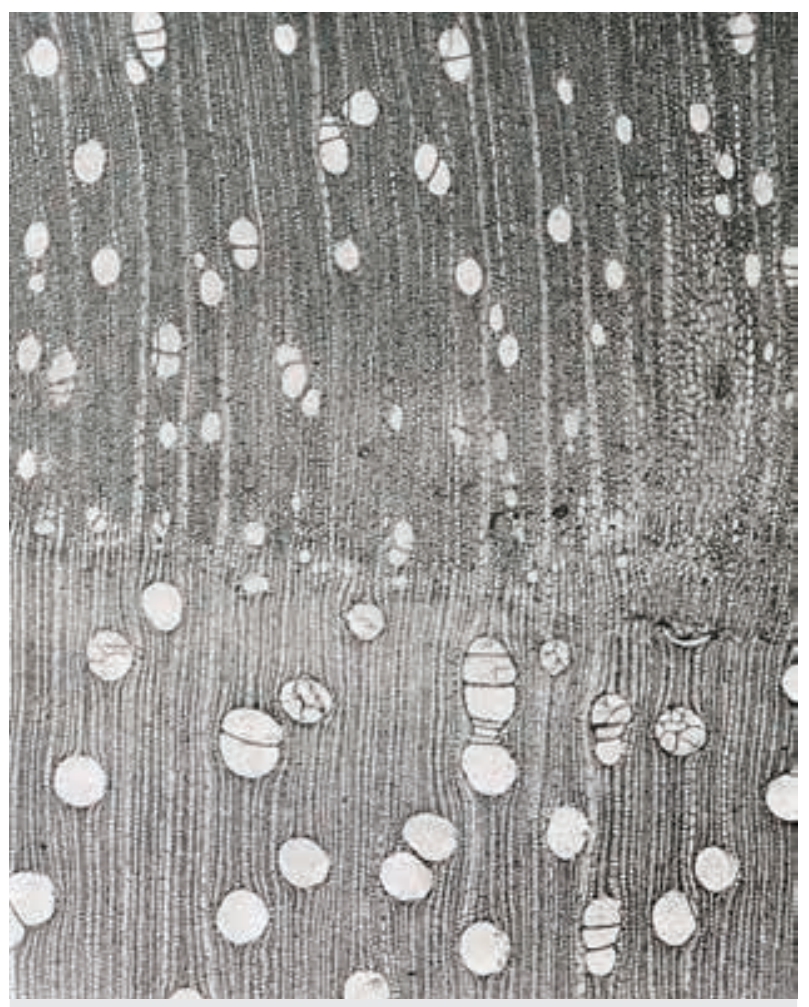

Photo 17.

A cross-section of okoume wood (Aucoumea klaineana Pierre) at the edge of a mark. To the right, scar tissue covering the normal wood and development of tyloses in the vessels. To the left, change in the aspect of the wood, indicating the position of the cambium at the time when the mark was made, even when it had cut into the wood.

Microphotograph J. Paquis. 


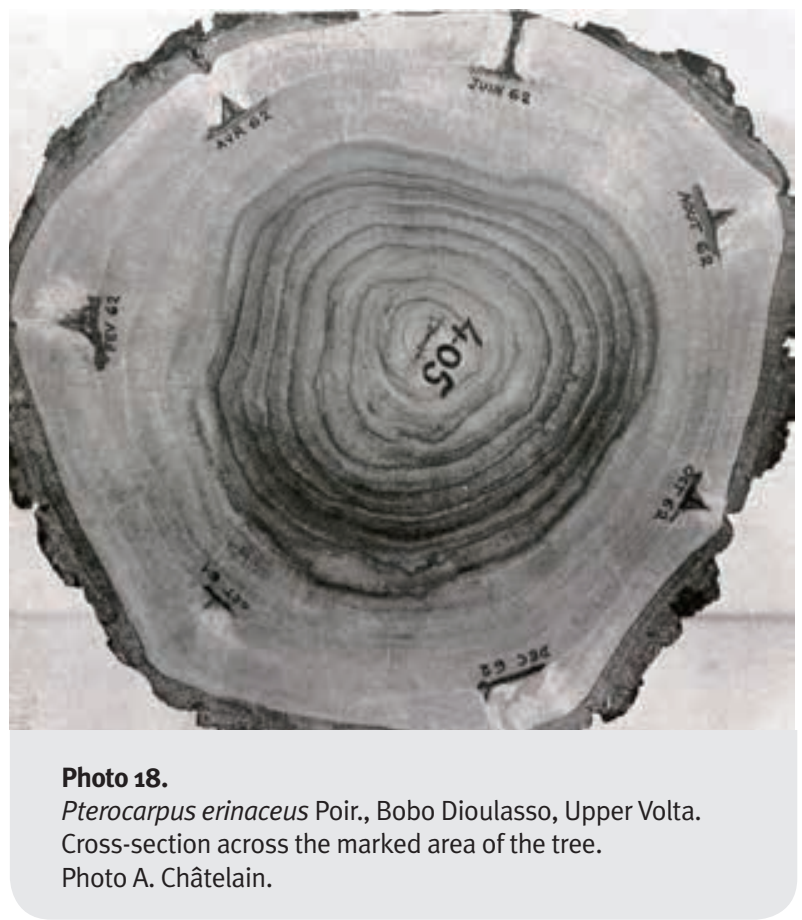

at the same time as we were taking the cambium samples, both in Upper Volta near Bobo Dioulasso and in Côte d'Ivoire near Bouaké. Every two months, an opening was made in the bark at the same height as the previous openings, working at regular intervals around the tree.

At Bobo Dioulasso, however, the first date (at the end of October) did not seem suitable for making successive marks in typically seasonal conditions, so the operation was postponed to 1 February. The 7 th mark was therefore made one year after the first mark at Bouaké and at Bobo Dioulasso a little later. In any case, from the first to the last marks at the start of the dry season, we had more or less defined an annual growth layer. We then waited another year before felling the trees in December 1963, so that a new layer of wood would correspond to one year exactly and to make sure that the scars would be entirely enclosed in the wood.

\section{Criticism of the method}

Several conclusions about the method can be drawn from this double series of tests.

- In general, the method met our expectations and allowed us to identify, within the cross sections, the outer limits of one year's growth with considerable accuracy.

- The size of the window opened into the bark was changed so that the saw blade could easily cut through all of the scars: these had to be at the same height, obviously, but they also had to be high enough. However, they were sometimes more than $2 \mathrm{~cm}$ in width, and the wood sometimes did not scar over completely, or became severely necrotic. Narrower marks were perfectly adequate and we now believe that the slip of bark removed can be no more than $5 \mathrm{~cm}$ in height and $1 \mathrm{~cm}$ in width.
- Our main concern with the first series of samples was to cut down as far as the wood but without actually cutting into it, as this could cause an incorrect appreciation of the position of the mark in the wood. Hence the need for extreme caution during the probable period of activity of the tree, because of the fragility of the wood as it forms and because it is not always easy to be sure that the cut has reached the wood, or whether any phloem is included. This extreme caution actually caused some failures, because the phloem and cambium sometimes remained intact: although the mark could still be seen in the bark, no trace of it remained in the wood. In fact, there is no drawback to scraping the wood at the bottom of the window to remove all of the cambium, since it is from the sides of the wound that the position of the mark in relation to the wood layers can be accurately identified.

- The method will obviously not work if growth has been very slight. In one case, the section only showed well-formed wood close to each mark, in the form of thick calluses (Lannea acida A. Rich., Bouaké).

- Some trees react to the smallest wound by forming abnormal layers of wood with abundant coloured parenchyma or trauma lines, in Detarium senegalense J.F. Gmel. and Ficus dicranostyla Mildbr. for example. The photograph on page 31 clearly shows the trauma lines that formed after each mark. These lines help to assess the different in level between successive marks that are due to wood formation, but they hamper the identification of what might be a normal annual growth ring.

\section{Initial results}

As we have said, the marking method was applied from October 1961 to December 1962 to two batches of trees: 14 at Bobo Dioulasso and 11 at Bouaké. Both were felled in early December 1963 (except for one tree left standing at Bouaké to continue the experiment).

The choice of species was essentially based on their local frequency. Because we had not yet made a detailed study of the nature and visibility of growth rings at the time, we did not restrict the choice to species with distinct growth rings.

Overall, the 24 trees examined produced the following results:

- Annual growth rings defined and countable:

Bobo Dioulasso: Senna siamea (Lam.) H.S. Irwin \& Barneby (planted); Daniellia oliveri (Rolfe) Hutch. \& Dalziel, Detarium microcarpum Guill. \& Perr., Isoberlinia doka Craib \& Stapf, Lannea acida A. Rich., Parkia biglobosa (Jacq.) R. Br. ex G. Don, Pterocarpus erinaceus Poir., Tectona grandis L. f. (planted), Vitex doniana Sweet,

Bouaké: Afzelia africana Sm. ex Pers., Anthocleista kerstingii Gilg ex Volkens, Senna siamea (Lam.) H.S. Irwin \& Barneby, Tectona grandis L. f.

- Growth rings indistinct, count uncertain: Bobo Dioulasso: Faidherbia albida (Delile) A. Chev. (1934) (but tree much damaged by numerous wounds), 
Vitellaria paradoxa C. F. Gaertn., Khaya senegalensis (Desr.) A. Juss., Terminalia laxiflora Engl. \& Diels,

Bouaké: Ficus dicranostyla Mildbr.

- Growth rings not discernible:

Bobo Dioulasso: Azadirachta indica A. Juss. (planted); Ficus dicranostyla Mildbr. (but cross section too asymmetrical, see photo),

Bouaké: Antiaris toxicaria var. africana Scott-Elliot ex A. Chev., Cussonia arborea Hochst. ex A. Rich. (nil growth), Daniellia oliveri (Rolfe) Hutch. \& Dalziel, Lannea acida A. Rich. (nil growth but other rings visible in the section), Vitex doniana Sweet (growth too slight).

We stress that readers should remember that each species mentioned is represented by only one tree, or at most one per station, and that the experiment lasted only two years. We believe our initial results are of great interest, but they should still be considered as a test of the method and further observations on the same species should be awaited before assessing possibilities for estimating their ages.

This is why we will only a make few general comments here rather than a detailed criticism of the results.

When the growth layers were thick enough for the levels of the first and last scars to be clearly distinguished, in other words the real or virtual tangential lines corresponding to the position of the cambium at the time when the first and last marks were made, at one-year intervals, the intermediate scars always situated the growth period in the rainy season, with growth ceasing in the dry season. Even in Bouaké, where the rains stop more or less in August, we did not observe any obvious double growth rings with clear outer limits in the course of the year, but only a false growth ring in a few cases that was distinct from the true outer limits (Tectona grandis L. f., Afzelia africana Sm. ex Pers.).

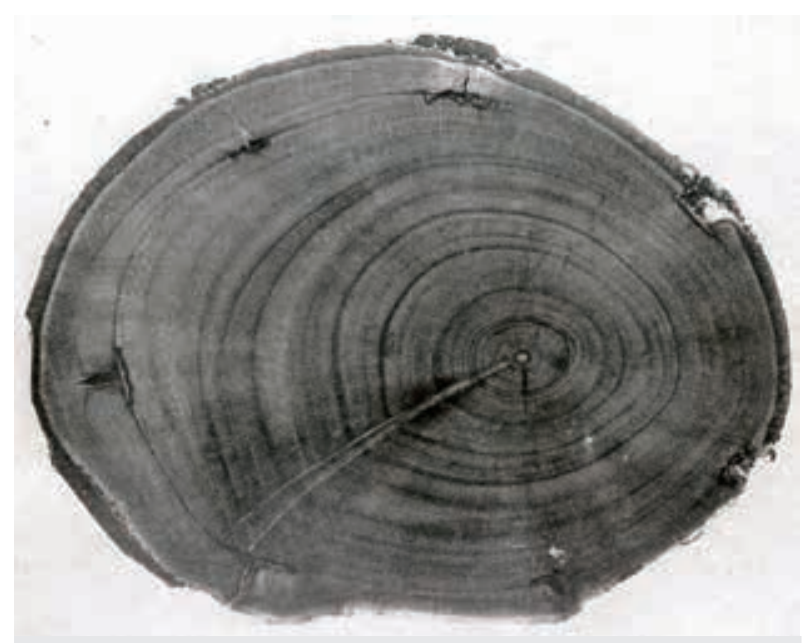

Photo 19.

Ficus dicranostyla Mildbr. (Bobo Dioulasso, Upper Volta). Cross-section of the tree, including marks. Trauma lines in specific areas, caused by making the marks, help to discern the differences in level but mask the true growth rings. Photo A. Châtelain.
We reserve our opinion in the case of Daniellia oliveri (Rolfe) Hutch. \& Dalziel: readers may have noted the discrepancy between the observations of the trees at Bobo Dioulasso and Bouaké. In the former, the 1962 and 1963 growth rings are clearly defined by a thin and continuous line of parenchyma, and the position of the marks clearly shows that the rings are annual. On the Bouake tree on the other hand, between the lines corresponding to the dormancy levels defined by the scars, several thick bands of parenchyma can be seen, and even some finer lines that can scarcely be considered as separate from the rings, so that what more or less appears are several very narrow growth layers in the same year, but which do not circle the section entirely. As this aspect seems to be specific to our Bouaké sample and is not found in the wood samples in our collection - Daniellia oliveri (Rolfe) Hutch. \& Dalziel from the Sudanian region, Daniellia oblonga Oliv., Daniellia klainei (Pierre) De Wild. etc. from dense forests - we provisionally hypothesised that the typical structure of a Daniella in its normal distribution range has an obvious terminal ring for each growth season, but without specifying whether there are two growth rings per year in dense forest trees. The Daniellia oliveri (Rolfe) Hutch. \& Dalziel trees at Bouaké and Bobo Dioulasso were growing under different climatic conditions. The structure of the Bouaké tree was disturbed and severely affected by sudden changes in a growing season that lasted too long.

We have gone into this case in some detail to show that the results are still limited and that it would be hazardous to draw any conclusions, either positive or negative, from the study of just one tree.

Nevertheless, the periodical marking method applied in this initial attempt has considerable advantages, in terms of simplicity and precision, for the determination of annual growth rings and even parts of a growth layer corresponding to different periods in the year.

We therefore extended the method to a large number of trees in different stations in tropical Africa, but using slightly different rules that we shall now describe, and which are those applied in our current research on this topic.

\section{Combining marks and dendrometric tape}

\section{Principle of the method}

To understand variations in the aspect of double growth layers that can cause several rings to form in the same year, or to note an absence of cambial dormancy that does not produce a growth ring, dated scars, one in each season for example, can only provide a rough guide while increasing the number of scars complicates comparisons of their levels, especially if the wood surface of the species does not lend itself to the marking method or if growth is only slight.

A theoretically simple way of accurately tracking the progress of wood formation is to make continuous and precise measurements of the circumference of a tree. 
A convenient method was communicated to us by J. Tariel, who had noted the usefulness, from a forester's point of view, of the method developed at the Colombus experimental sylvicultural station in the United States (FAO, Note on forestry equipment, $n^{\circ} \mathrm{A} 10.58$, on locally manufactured dendrometers, December 1957).

A metal tape is placed around the tree, the two ends being attached together by means of a spring fixed to either end of the tape so as to enclose it over a sufficient length for a vernier caliper on one of the ends to slide over a graduated scale on the other end.

The set-up can remain in place for years and can be read at any time. When compared, the readings show how far the ends have been sliding over each other, and hence the growth in circumference of the tree.

Marking each tree once a year and taking frequent readings from the dendrometric tape produces accurate knowledge of wood formation over one year, with minimum difficulty or damage to the tree.

It is worth exercising patience and continuing the observations over several years in order to identify several successive annual growth layers in the wood.

The difficulty lies in choosing the date on which to mark the trees, although it is not absolutely crucial to have a oneyear interval between two marks. The result will be clearer if the marks can be placed exactly on the outer limits of the rings. The long dry season can be chosen in both dense forest areas and savannah. An additional mark can be made at the time when the trees come into leaf, if this happens at a different time of year.

\section{Applying the method}

A stylus and a metal template incised with the required divisions are all that is needed to trace the divisions onto the tape, and as many of these dendrometers as required can be placed on trees at little expense, since only the tape and one spring are used for each tree.

The template, over which the tape can easily be tightened to trace the lines, is incised with $2 \mathrm{~mm}$ divisions; the vernier caliper will measure $1 / 10$ th of a division, or $1 / 5 \mathrm{~mm}$. For the sake of simplicity, all readings are made by 1 division and $1 / 10$ of a division, with the conversion done later on paper.

In collaboration with J. Tariel and A. Marcel-Best, we set up an initial series of observations in Bouaké during the 1963-64 dry season, combining marks and tape. The trees were felled in March 1966. During the two years of observation, the dendrometric tapes were read once a month.

Since then, other observation stations have opened, as indicated below. The trees had not yet been felled at the time of writing, but regular visits are made every fortnight or every month, depending on the availability of the local officer. Difficulties and particularities in the readings already make up a substantial file of documentation enabling us to appraise the method, or at least to draw attention to certain points.

\section{Difficulties encountered with dendrometric tape}

\section{Disturbance to the tape}

One weak point with this method, which is also an advantage, is that the tape remains on the tree and is monitored only intermittently. In some stations, there have been cases where hunters have found the springs to be useful for other purposes, and the tape is then found on the ground or has also disappeared. Besides this extreme case, the tape can be shifted slightly by falling branches or by animals climbing up the tree. This necessarily produces an error the next time the divisions are read. We attempted to remedy this by placing three small nails below the tape to support it and ensure that it remained in position. This was successful at Bouaké, but we did not attempt it in the other stations in case the cambium began to form a callus around the nails, but this did not happen on the tree at Bouaké.

In fact, if the position of the tape is clearly marked on the tree - and this occurs naturally quite soon because the bark changes in colour - the tape can be put back into position and a new reading taken, with a mention of the disturbance. The graphs plotted from the readings show that this kind of disturbance does not usually affect the interpretation of the tree's growth (pg. 35).

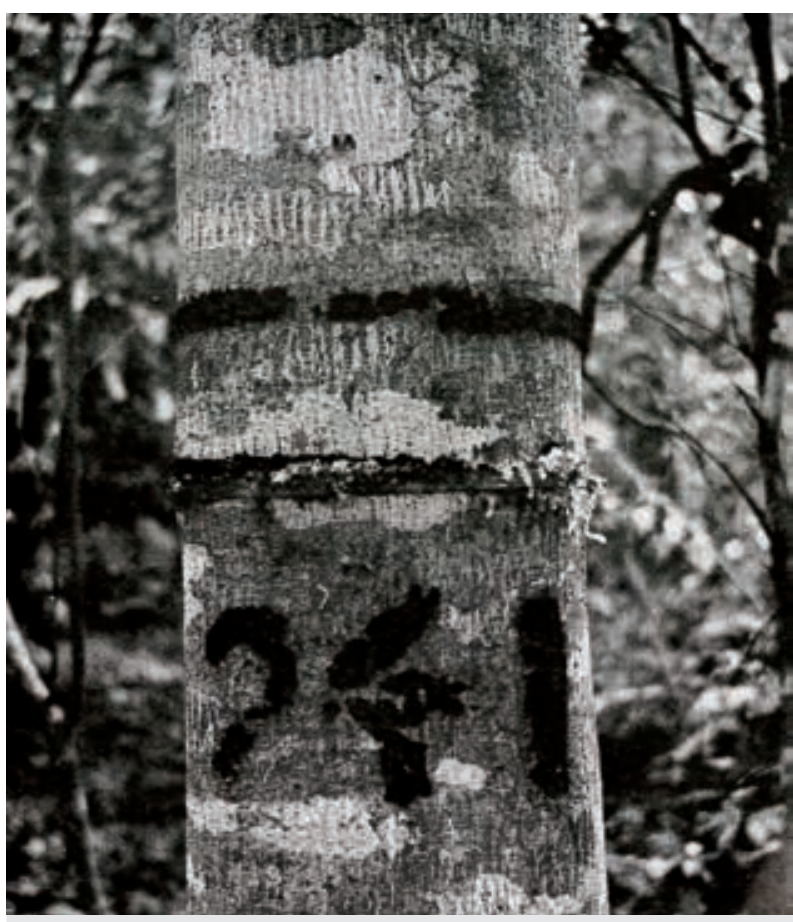

Photo 20.

A mahogany tree (Khaya grandifoliola C. DC.) at Bouaké (Côte d'Ivoire). Reaction of the bark, which swelled and produced gum below the dendrometric tape (and flaked off below the paint) one year after positioning the tape.

Photo A. Mariaux 


\section{Temperature variations}

With this method, the tape is the measuring instrument, which means that its length should not vary. Any elongation or shrinkage of the tape caused by temperature variations will result in an incorrect interpretation of variations in circumference.

In dense forest, where temperature variations in the understory are moderate, there is less risk of error than in clear savannah forest where temperatures vary widely over 24 hours. Pending more accurate observations, we noted the following results on 3 February 1965 in Niamey, from a tape placed on a tree trunk about $20 \mathrm{~cm}$ in diameter and exposed to sunlight in mid-afternoon:

- 8 a.m., very cool temperature, division ...................1.1

- 1 p.m., very hot, tape in the shade......................... 0.95

- 4 p.m., tape in the sun.................................................. 0.75

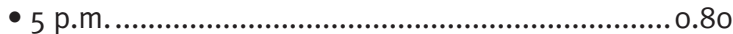

The maximum error was therefore of 0.35 of a division, or $0.7 \mathrm{~mm}$. The error would have been greater if the tree had been larger. Although it is not negligible, practically speaking this is the maximum error. Readings should be made quite regularly at the same time of day, so that the graph does not show small misleading variations, which would mainly raise problems with very slow growing trees.

\section{Bark contraction}

Most of the graphs plotted from the dendrometric readings in Bouaké level off during the dry season, reflecting a pause in growth. They even show a slight reduction in circumference, of the order of one division, corresponding to $300 \mu$ across the radius. Chowdhury indicated a contraction of the cambium during the dormancy period, followed by swelling before growth resumed. We wondered whether the bark might not also contract in dry air, which could partly mask an increment. It might even be considered that there is no real pause in wood formation, the increment being temporarily offset by bark contraction. This point needs further investigation.

In fact, it seems that graphs such as the one we have presented for an iroko in Bouaké cannot be accounted for by bark retraction alone and without a marked slowdown or pause in cambium activity.

\section{Reactions of the tree}

In general, the presence of a metal tape around the bark did not produce any reaction. Up to now, only the mahoganies (Khaya sp. pl.) sometimes reacted by forming a callus with gum production and insect attacks, to the point where the variations indicated by the tape became meaningless.

For the same reasons, we stopped placing tape on bossé trees (Leplaea cedrata (A. Chev.) E.J.M. Koenen \& J. J. de Wilde), as the bark seemed flake off constantly, preventing accurate comparisons between readings.

\section{Initial results from the method combining marks and dendrometric tape readings}

As we have indicated, the first trees on which marks were made and dendrometric tape placed were near Bouaké in Côte d'Ivoire, specifically at the Kokondékro forestry station, which covers a patch of dense forest and savannah areas that have been almost entirely replanted with teak.

This is why this series, like the series using frequent periodical marking, includes savannah species, but especially deciduous forest species.

During the 1963-64 dry season, tapes were placed on 20 trees, but four of these were not to be felled, so that the first mark was made in February 1964 on 16 trees. The second mark was made in February 1965.

In early March 1966, 12 trees were felled (the other four were left aside for various reasons: large calluses on a mahogany, broken or fallen trees).

Of the discs cut at the height of the marks from the 12 felled trees, one had no scars in the wood, indicating that the

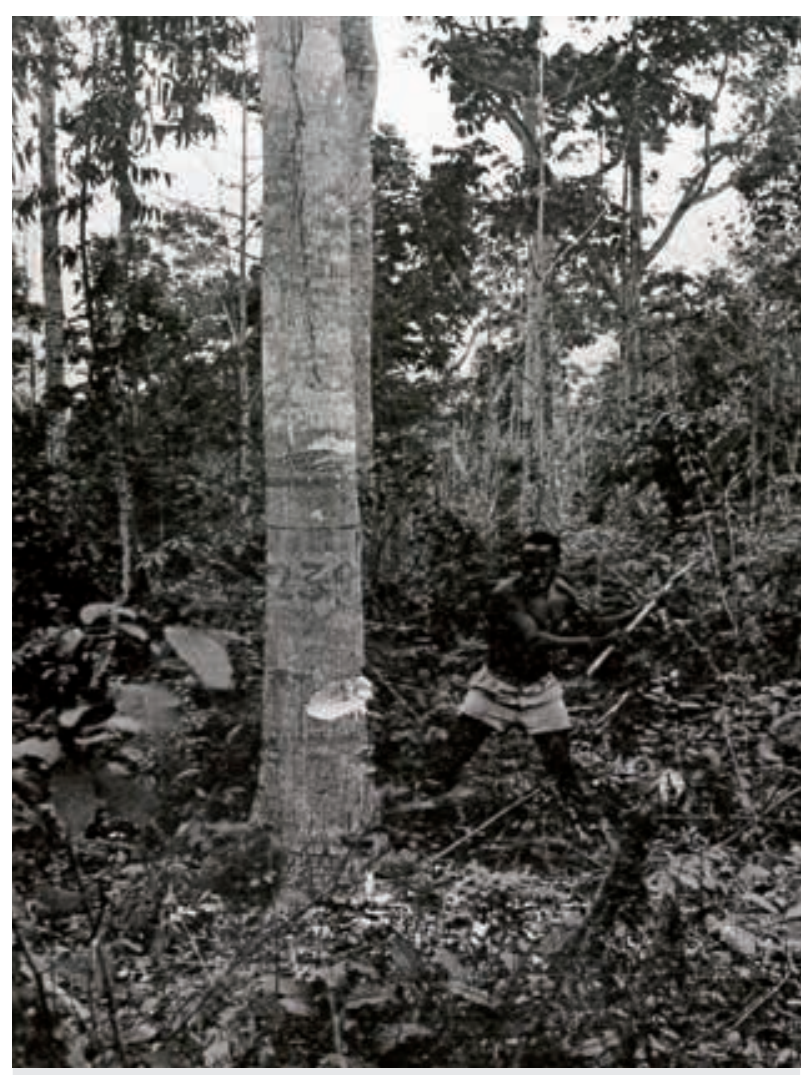

Photo 21.

Iroko nº 239 (Milicia excelsa (Welw.) C.C. Berg), Bouaké, Côte d'Ivoire. Tree felled on 10 March 1966 after two years of dendrometric measurements, with marks made on 23 December 1963 and 12 February 1965. Photo A. Mariaux. 
marks had not been cut down to the cambium. This tree, a samba (Triplochiton scleroxylon K. Schum.), provides an example of the problem mentioned previously, where the phloem is too similar to the wood to be sure that the cut has penetrated far enough.

The tape placed on one non-suppressed teak (Tectona grandis L. f.), chosen in a fairly vigorously growing parcel, showed no growth at all, but displayed random variations that were probably due to the bark. The section nevertheless shows growth of about one millimetre up to the final mark. The first mark did not reach the wood. As already proven by the other marks, the annual growth layer corresponds to the growth ring ending in a line of parenchyma and a porous band.

The experiments therefore proceeded normally with only 10 trees, i.e. those with two marks properly positioned in the wood, sufficient growth for the rings to be analysed and tape readings with minimal discontinuity.

Six trees produced a positive result, i.e., annual growth rings corresponding to the position of the marks and to the period of leaf fall in the dry season, with a dormancy period clearly reflected in the levelling off of the graph plotted from the tape readings over time.

The six results are illustrated here by the example of the iroko (Milicia excelsa (Welw.) C.C. Berg). All the graphs are in fact very similar (except for the amplitude due to the growth rate) (figure 2 ).

The $X$ axis shows the observation period, month by month, and the $Y$ axis shows the cumulative increment across the radius (wood formation) calculated by conversion of the successive readings of the dendrometric tape.

It should be noted that the dry season in the Bouake region lasts from November to March (with fairly wide variations from year to year).

The figure 2 shows that the dormancy period was quite variable: from December (or before) to May in 1963-64, from December to March or April (intervals between readings too large) in 1964-65 and from August to March (or later) in 196566. The trees came into leaf during these periods. Growth did not slow down during the short and very relatively dry season in 1964, in July and August. However, in July-August 1965 , growth not only slowed down but actually stopped, and did not resume in September-October.

Also to be noted is that the rate of growth (slope of the curve) was very similar in 1964 and 1965 , but that the layer of wood formed in 1965 was three times narrower than in the previous layer, due to the early onset of cambium dormancy.

On the photograph of the wood, the two scars showing the levels in December 1963 and February 1965 can be clearly seen, well within the thin tangential line of parenchyma

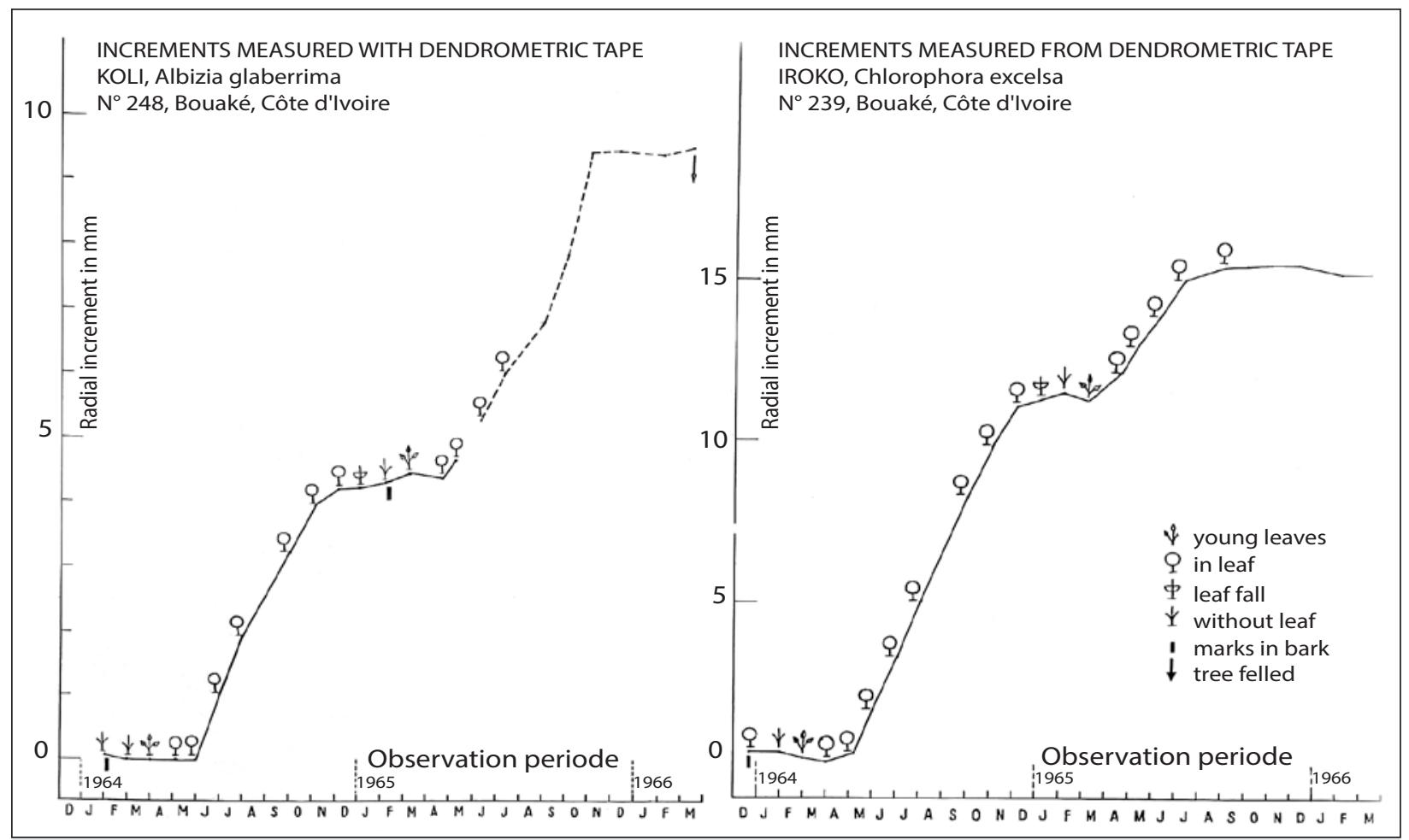

Figure 2.

Example of increment across the radius for two trees, koli (Albizia glaberrima (Schumach. \& Thonn.) Benth.) et iroko (Milicia excelsa (Welw.) C.C. Berg). The $X$ axis shows the observation period, month by month, and the $Y$ axis shows the cumulative increment across the radius (wood formation) calculated by conversion of the successive readings of the dendrometric tape. One graph shows the measures done on the iroko $n^{\circ} 239$ (photos $21 \& 22$ ). 
corresponding to what is described as the "outer limit of the growth ring", which is more or less paralleled by a darker zone with no parenchyma and a change in the overall aspect of the parenchyma associated with the vessels. There is no ring limit between the two scars, which confirms that growth did not slow down, or between the second scar and the periphery of the wood.

These are therefore annual growth rings, and it may be considered that any growth ring identified towards the center is also an annual ring.

One difficulty remains, however: if we follow the last line of parenchyma round at the level of the second mark (between the rings for 1964 and 1965), we note that it almost disappears in places. The tapering line of parenchyma and the overall aspect of the wood at this level produces the impression of a line that might have been considered as a false growth ring and ignored in the ring count. This raises doubts over the other levels in the section, which we might have been tempted to interpret erroneously as false growth rings.

Nevertheless, insofar as this is confirmed by other trees, we will have demonstrated that normal growth rings in the iroko tree were formed by an annual increments.

The other trees that produced similar results were:

- A kapok (Ceiba pentandra (L.) Gaertn.),
- A tali (Erythrophleum suaveolens (Guill. \& Perr.) Brenan),

- A limba (Terminalia superba Engl. \& Diels), which also had seven marks from the 1961-62 series,

- A Vitex doniana Sweet,

- A candlewood tree (Zanthoxylum zanthoxyloides (Lam.) Zepern. \& Timler).

The last two required very detailed examination of the wood to discern the very faint growth rings.

Four trees produced a provisionally negative result. These are species in which the annual growth cycle includes a dormancy phase, as shown by the graphs, but in which growth rings cannot easily be discerned on the surface of the wood:

- A Cola cordifolia (Cav.) R. Br., where the aspect of the concentric bands of parenchyma varies slightly along the level of the scars, but where the change in aspect cannot be seen with any certainty across the entire section,

- An ako (Antiaris toxicaria var. africana Scott-Elliot ex A. Chev.),

- An aiélé (Canarium schweinfurthii Engl.), with growth rings of a similar type to those in okoume wood, formed by variations in density, and for which the $x$-ray technique could help to discern the annual increments clearly.

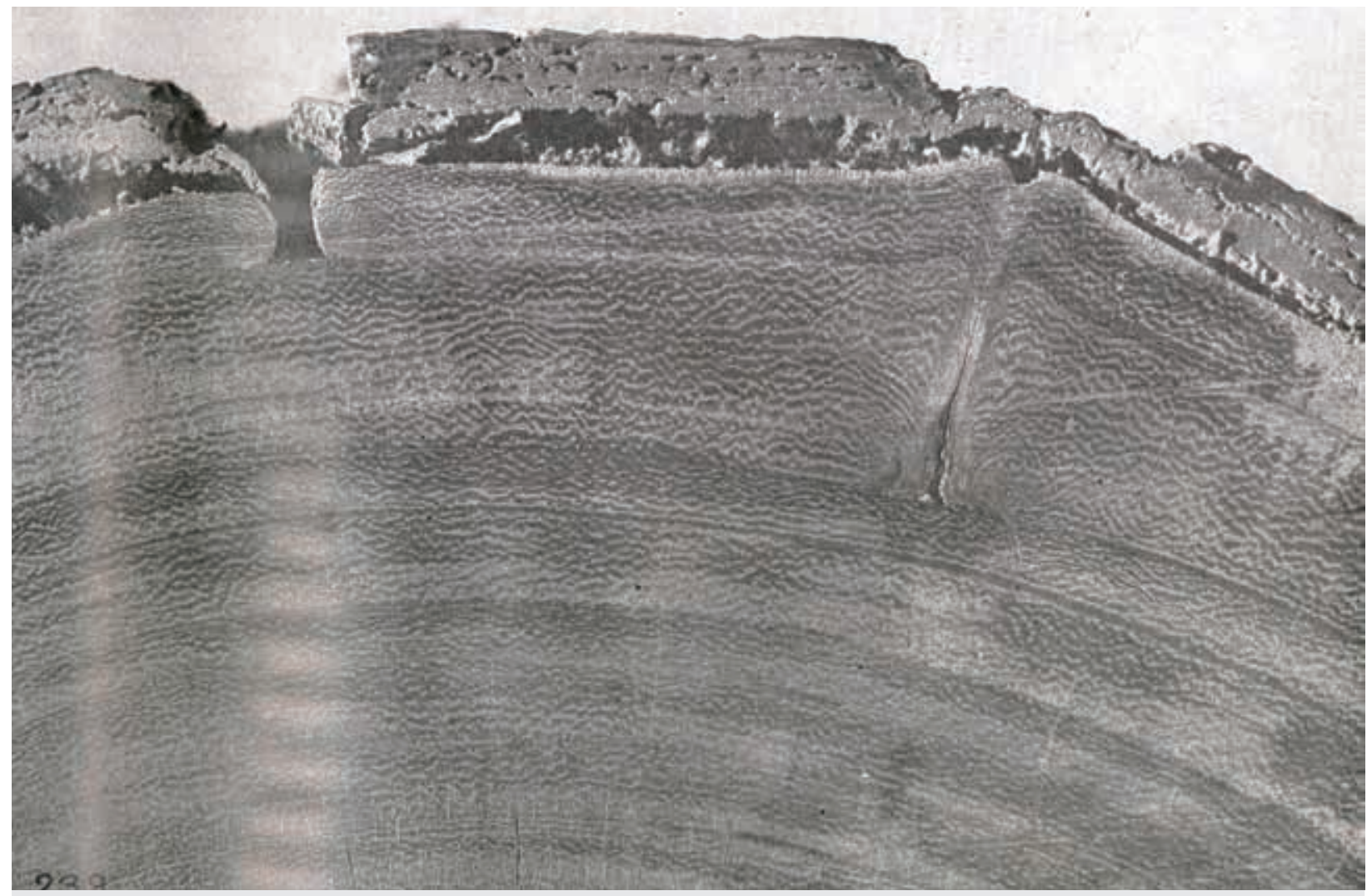

Photo 22.

The same iroko (Milicia excelsa (Welw.) C.C. Berg), $\mathrm{n}^{\circ} 239$, cross-section of the bole through the marks. Photo A. Châtelain. 
Table III.

Species observed to determine the rhythm of growth ring formation in dense forest.

\begin{tabular}{|c|c|c|c|c|c|c|}
\hline Scientific name & Trade name & $\begin{array}{c}\text { Senegal } \\
\text { (Casamance) }\end{array}$ & Côte d'Ivoire & Cameroon & Gabon & Congo \\
\hline Afzelia sp. & Doussié & & & 4 & & \\
\hline Albizia spp. & & 4 & 1 & & & \\
\hline $\begin{array}{l}\text { Antiaris toxicaria var. africana } \\
\text { Scott-Elliot ex A. Chev. }\end{array}$ & Ako & 1 & 2 & & & \\
\hline Aucoumea klaineana Pierre & Okoumé & & 3 & 3 & 40 & \\
\hline Ceiba pentandra (L.) Gaertn. & Fromager & & 1 & & & \\
\hline Milicia excelsa (Welw.) C.C. Berg & Iroko & 1 & 3 & 8 & & \\
\hline $\begin{array}{l}\text { Entandrophragma angolense } \\
\text { (Welw.) C. DC. }\end{array}$ & Tiama & & 8 & & & \\
\hline $\begin{array}{l}\text { Entandrophragma candollei } \\
\text { Harms }\end{array}$ & Kosipo & & 2 & 2 & & \\
\hline $\begin{array}{l}\text { Entandrophragma cylindricum } \\
\text { (Sprague) Sprague }\end{array}$ & Sapelli & & 3 & 13 & & \\
\hline $\begin{array}{l}\text { Entandrophragma utile } \\
\text { (Dawe \& Sprague) Sprague }\end{array}$ & Sipo & & 8 & 1 & $\begin{array}{l}3 \text { (whitout } \\
\text { measuring } \\
\text { tape) }\end{array}$ & \\
\hline Fagara spp. & Olon & & 1 & 1 & & \\
\hline $\begin{array}{l}\text { Leplaea cedrata (A. Chev.) } \\
\text { E.J.M. Koenen \& J. J. de Wilde }\end{array}$ & Bossé & & 3 & 1 & & \\
\hline Khaya ivorensis A. Chev. & Acajou & & 4 & 2 & & \\
\hline $\begin{array}{l}\text { Mansonia altissima (A. Chev.) } \\
\text { A. Chev. }\end{array}$ & Bélé & & 3 & & & \\
\hline Morus mesozygia Stapf & Difou & & 1 & & & \\
\hline $\begin{array}{l}\text { Pycnanthus angolensis } \\
\text { (Welw.) Warb. }\end{array}$ & Ilomba & & & 7 & & \\
\hline Tarrietia utilis (Sprague) Sprague & Niangon & & 8 & 2 & & \\
\hline Tectona grandis L. f. & Teck & & 3 & 2 & & \\
\hline Terminalia ivorensis A. Chev. & Framiré & & 3 & 3 & & \\
\hline Terminalia superba Engl. \& Diels & Limba & & 1 & 4 & & 25 \\
\hline $\begin{array}{l}\text { Tieghemella heckelii (A. Chev.) } \\
\text { Pierre ex Dubard }\end{array}$ & Makoré & & 6 & & & \\
\hline $\begin{array}{l}\text { Triplochiton scleroxylon } \\
\text { K. Schum. }\end{array}$ & Samba & & 5 & 7 & & \\
\hline
\end{tabular}

\section{Extending our observations}

In this article, we have only described very limited results obtained by different methods. We have deliberately not attempted to group them by species when the case arose. Nor have we compared them, when possible, with observations cross sections from trees of known age.

The reason is that our main purpose was to describe the results of the methods used.
In fact, the method combining marks and dendrometric tape was adopted to extend our investigations to more stations and to species of general use, or at least of local interest.

As far as possible, several trees of the same species were chosen in each station to avoid particular cases. We intend to fell some of the trees after two years of observation and to leave the others standing for several years, marking them each year as before, to increase the amount of data collected for each tree. 
Table IV.

Species observed to determine the rhythm of growth ring formation in savannah.

\begin{tabular}{|c|c|c|c|c|}
\hline Scientific name & Senegal & $\begin{array}{c}\text { Upper Volta } \\
\text { (Burkina Faso) }\end{array}$ & Niger & Côte d'Ivoire \\
\hline Acacia spp. & & 2 & 4 & \\
\hline $\begin{array}{l}\text { Faidherbia albida (Delile) } \\
\text { A. Chev. (1934) }\end{array}$ & 2 & 5 & & \\
\hline Albizia spp. & 4 & & 3 & \\
\hline Afzelia africana Sm. ex Pers. & 1 & 5 & & 1 \\
\hline Anogeissus (DC.) Wall. & & 3 & & \\
\hline Vitellaria paradoxa C. F. Gaertn. & & 6 & & \\
\hline Combretum spp. & & & 3 & \\
\hline $\begin{array}{l}\text { Daniellia oliveri (Rolfe) } \\
\text { Hutch. \& Dalziel }\end{array}$ & & 2 & & 1 \\
\hline Isoberlinia doka Craib \& Stapf & & 5 & & \\
\hline Khaya senegalensis (Desr.) A. Juss. & 1 & 1 & $5(p)$ & \\
\hline $\begin{array}{l}\text { Parkia biglobosa (Jacq.) } \\
\text { R. Br. ex G. Don }\end{array}$ & & 1 & & \\
\hline Pterocarpus erinaceus Poir. & 1 & 5 & & \\
\hline Sterculia setigera Delile & & 1 & & \\
\hline Terminalia laxiflora Engl. \& Diels & & 2 & & \\
\hline Diverse & & 11 & 5 & 7 \\
\hline Various exotics & & 3 & 5 & 1 \\
\hline
\end{tabular}

We have reserved the other methods - several marks a year, cambium samples - for particular cases, or to help clarify uncertainties at a later stage.

The tables III \& IV below show the importance of these observations today by showing the distribution of the species studied in each country. The following are the stations where the observations are taking place, thanks to the help of the CTFT units (Cirad) in the different countries:

- Senegal: Djibelor (Zinguichor) - Diourbel,

- Upper Volta: Toumousséni (Banfora) - Dinderesso

(Bobo Dioulasso) - Gonsé (Ouagadougou),

- Niger: Koromata (Saï),

- Côte d'Ivoire: Kokondékré and Bamoro (Bouaké) -

Sangoué (Oumé) - Bouaflé - Yapo - Banco (Abidjan),

- Cameroon: Kienkié (Kribi) - Akoamimbang (M’Balmayo)

- Kendongi (Kumba),

- Gabon:Mondahand Ikoy-Bandja (Libreville) - N’Koulounga

- M’Bel,

- Congo: M’Boku N’Situ.

\section{Bibliographical references}

Bowers N. A., 1964. New method of surfacing wood specimens for study. Tree-ring Bulletin, 26 (1/4), Tucson, Arizona, 1964 .
Chowdhury K. A., 1939-1940. The formation of growth rings in Indian trees. Indian Forest Records, 2 (1), 1939; 2 (2) and 2 (3), 11-140.

Coster Ch., 1927-1928. Zur Anatomie und Physiologie der Zuwachszonen - und Jahresringbildung in den Tropen Ann. Jard. Bot. Buitenz. vol. XXXVII, 1927, und vol. XXXVIII, 1928.

Hummel F. C., 1946. The formation of growth rings in Entandrophragma macrophyllum A. Chev. and Khaya grandifoliola C. D. C. Empire Forestry Review, 25 (1).

Kisser J., Lehnert I., 1951. Un nouveau procédé pour distinguer le bois initial du bois final chez les conifères. Mitt. Osterr. Ges. für Holzforschung, Vienne, 3 (1).

Lowe R. G., 1959. Periodic growth in Triplochiton scleroxylon K. Schum. Technical note $n^{\circ} 13$, Dep. For. Research, Ibadan, Nigeria, introduced at the 13 th IUFRO Congress, Viena, 25/5-S/5.

Patterson A. E., 1959. Distinguishing annual rings in diffous porous tree species. Journal of Forestry, 57 (2).

Polge H., 1963. L'analyse densitométrique des clichés radiographiques. Annales de l'École Nationale des Eaux et Forêts, $\mathrm{XX}, 4$, Nancy.

Tchinkel H. M., 1963. Annual growth rings in Cordia alliodora. Turrialba, vol. $16, n^{\circ} 1$. 


\section{Appendice I.}

Liste of scientific names used in the text and figures by the author, and corrected or modernized by the journal with the assistance of Michel Arbonnier (Cirad).

\begin{tabular}{|c|c|}
\hline $\begin{array}{l}\text { Botanic name used by the author } \\
\text { and transcribed in the original article }\end{array}$ & Corrected name of genus and species or botanic synonymy \\
\hline Acacia albida & Faidherbia albida (Delile) A. Chev. (1934) \\
\hline Acacia catechu & Acacia catechu (L. f.) Willd. \\
\hline Afzelia africana & Afzelia africana Sm. ex Pers. \\
\hline Afzelia bipidensis & Afzelia bipindensis Harms \\
\hline Albizia lebbek & Albizia lebbeck (L.) Benth. \\
\hline Albizia glaberrima & Albizia glaberrima (Schumach. \& Thonn.) Benth. \\
\hline Anogeissus sp. & Anogeissus (DC.) Wall. \\
\hline Anthocleista kerstingii & Anthocleista kerstingii Gilg ex Volkens \\
\hline Antiaris africana & Antiaris toxicaria var. africana Scott-Elliot ex A. Chev. \\
\hline Aucoumea klaineana & Aucoumea klaineana Pierre \\
\hline Azadirachta indica & Azadirachta indica A. Juss. \\
\hline Berlinia granidiflora & Berlinia grandiflora (Vahl) Hutch. \& Dalziel \\
\hline Bombax malabaricum & Bombax ceiba L. \\
\hline Butyrospermum parkii & Vitellaria paradoxa C. F. Gaertn. \\
\hline Canarium schweinfurthii & Canarium schweinfurthii Engl. \\
\hline Cassia fistula & Cassia fistula L. \\
\hline Cassia siamea & Senna siamea (Lam.) H.S. Irwin \& Barneby \\
\hline Cedrela toona & Toona ciliata M. Roem. \\
\hline Ceiba pentandra & Ceiba pentandra (L.) Gaertn. \\
\hline Chlorophora excelsa & Milicia excelsa (Welw.) C.C. Berg \\
\hline Cola cordifolia & Cola cordifolia (Cav.) R. Br. \\
\hline Cordia alliodora & Cordia alliodora (Ruíz \& Pav.) Oken \\
\hline Cussonia djalonensis & Cussonia arborea Hochst. ex A. Rich. \\
\hline Dalbergia sissoo & Dalbergia sissoo Roxb. ex DC. \\
\hline Daniellia klainea & Daniellia klainei (Pierre) De Wild. \\
\hline Daniellia oliveri & Daniellia oliveri (Rolfe) Hutch. \& Dalziel \\
\hline Daniellia thurifera & Daniellia oblonga Oliv. \\
\hline Detarium senegalense & Detarium senegalense J.F. Gmel. \\
\hline Detarium microcarpum & Detarium microcarpum Guill. \& Perr. \\
\hline Entandrophragma angolense & Entandrophragma angolense (Welw.) C. DC. \\
\hline Entandrophragma candollei & Entandrophragma candollei Harms \\
\hline Entandrophragma cylindricum & Entandrophragma cylindricum (Sprague) Sprague \\
\hline Entandrophragma utile & Entandrophragma utile (Dawe \& Sprague) Sprague \\
\hline Erythrophleum guineensis & Erythrophleum suaveolens (Guill. \& Perr.) Brenan \\
\hline Fagara xanthoxyloides & Zanthoxylum zanthoxyloides (Lam.) Zepern. \& Timler \\
\hline
\end{tabular}




\begin{tabular}{|c|c|}
\hline Ficus dicranostyla & Ficus dicranostyla Mildbr. \\
\hline Guarea cedrata & Leplaea cedrata (A. Chev.) E.J.M. Koenen \& J. J. de Wilde \\
\hline Homalium tomentosum & $\begin{array}{l}\text { Flacourtiaceae Homalium tomentosum Benth. -- J. Proc. Linn. Soc., Bot. 4: } 34 . \\
1859 \text { [1860 publ. 1859] (IK). Species native to Java. }\end{array}$ \\
\hline Isoberlinia doka & Isoberlinia doka Craib \& Stapf \\
\hline Khaya grandifolia & Khaya grandifoliola C. DC. \\
\hline Khaya ivorensis & Khaya ivorensis A. Chev. \\
\hline Khaya senegalensis & Khaya senegalensis (Desr.) A. Juss. \\
\hline Lagerstroemia speciosa & Lagerstroemia speciosa (L.) Pers. \\
\hline Lannea acida & Lannea acida A. Rich. \\
\hline Mansonia altissima & Mansonia altissima (A. Chev.) A. Chev. \\
\hline Melia azedarach & Melia azedarach L. \\
\hline Michelia champaca & Magnolia champaca (L.) Baill. ex Pierre \\
\hline Morus mesozygia & Morus mesozygia Stapf \\
\hline Nauclea latifolia $=$ Nauclea esculenta & Sarcocephalus latifolius (Sm.) E. A. Bruce \\
\hline Parkia biglobosa & Parkia biglobosa (Jacq.) R. Br. ex G. Don \\
\hline Peronema canescens & $\begin{array}{l}\text { Lamiaceae Peronema canescens Jack -- Malayan Misc. ii. (1822) n. VII. 46. (IK) } \\
\text { Malayan Miscellanies 2(7): 46. 1822. Species native to Malaya. }\end{array}$ \\
\hline Pinus longifolia & Pinus roxburgii Sarg. \\
\hline Pterocarpus angolensis & Pterocarpus angolensis DC. \\
\hline Pterocarpus erinaceus & Pterocarpus erinaceus Poir. \\
\hline Pterocarpus indiens & Pterocarpus indicus Willd. \\
\hline Pycnanthus angolensis & Pycnanthus angolensis (Welw.) Warb. \\
\hline Sterculia seligera & Sterculia setigera Delile \\
\hline Swietenia macrophylla & Swietenia macrophylla King \\
\hline Tarrieta utilis & Tarrietia utilis (Sprague) Sprague \\
\hline Tectona grandis & Tectona grandis L. f. \\
\hline Terminalia glaucescens & Terminalia schimperiana Hochst. \\
\hline Terminalia ivorensis & Terminalia ivorensis A. Chev. \\
\hline Terminalia laxiflora & Terminalia laxiflora Engl. \& Diels \\
\hline Terminalia superba & Terminalia superba Engl. \& Diels \\
\hline Terminalia tomentosa & $\begin{array}{l}\text { Combretaceae Terminalia tomentosa Mart. ex Eichler (nom illégitime) -- Fl. Bras. } \\
\text { (Martius) } 14(2): 97 \text {, in syn. } 1867 \text { [17 Apr 1867] (IK). } \\
\text { Terminalia tomentosa Wight \& Arn. (1834). } \\
\text { Terminalia tomentosa var. coriacea C.B. Clarke - The Flora of British India 2: } \\
\text { 448. 1878. All species native to India. }\end{array}$ \\
\hline Tieghemella heckelii & Tieghemella heckelii (A. Chev.) Pierre ex Dubard \\
\hline Toona sureni & $\begin{array}{l}\text { Meliaceae Toona sureni Merr. -- Interpr. Rumph. Herb. Amboin. } 305 \text { (1917). (IK). } \\
\text { Revision of genus Toona in } 1988 \text { by Bahadur. Species native to South-East Asia } \\
\text { and India. }\end{array}$ \\
\hline Triplochyton scleroxylon & Triplochiton scleroxylon K. Schum. \\
\hline Uapaca Somon & Uapaca togoensis Pax \\
\hline Vitex cuneata & Vitex doniana Sweet \\
\hline
\end{tabular}

